\title{
Landowner Outreach Education Project Evaluation: Connecting New Family Forest Owners with the Professional Forestry Community
}

\author{
Megan E. McCuen \\ West Virginia University
}

Follow this and additional works at: https://researchrepository.wvu.edu/etd

\author{
Recommended Citation \\ McCuen, Megan E., "Landowner Outreach Education Project Evaluation: Connecting New Family Forest \\ Owners with the Professional Forestry Community" (2012). Graduate Theses, Dissertations, and Problem \\ Reports. 3533. \\ https://researchrepository.wvu.edu/etd/3533
}

This Thesis is protected by copyright and/or related rights. It has been brought to you by the The Research Repository @ WVU with permission from the rights-holder(s). You are free to use this Thesis in any way that is permitted by the copyright and related rights legislation that applies to your use. For other uses you must obtain permission from the rights-holder(s) directly, unless additional rights are indicated by a Creative Commons license in the record and/ or on the work itself. This Thesis has been accepted for inclusion in WVU Graduate Theses, Dissertations, and Problem Reports collection by an authorized administrator of The Research Repository @ WVU. For more information, please contact researchrepository@mail.wvu.edu. 


\title{
Landowner Outreach Education Project Evaluation:
}

\section{Connecting New Family Forest Owners with the Professional Forestry Community}

\author{
Megan E. McCuen
}

\author{
Thesis submitted to the \\ Davis College of Agriculture, Natural Resources and Design \\ at West Virginia University \\ in partial fulfillment of the requirements \\ for the degree of \\ Master of Science \\ in \\ Forestry \\ David W. McGill, Ph.D., Chair \\ Kathryn G. Arano, Ph.D. \\ Sheldon F. Owen, Ph.D.
}

Division of Forestry and Natural Resources

\author{
Morgantown, West Virginia
}

2012

Keywords: Family forest owners, outreach, landowner education 


\title{
ABSTRACT \\ Landowner Outreach Education Project Evaluation: Connecting New Family Forest Owners with the Professional Forestry Community
}

\author{
Megan E. McCuen
}

The majority of West Virginia's forested land is owned by private family forest owners. These individually owned woodlands significantly impact the whole landscape. Connecting with this population and linking them with services and organizations that offer support is essential as these individuals and families establish their ideal woodland. Absentee landowners, land transfers, and increasing industry and development bring to the landscape a high risk for parcelization and fragmentation. With knowledge and forest management information, many woodland owners can improve the overall health, sustainability, and productivity of these lands.

One of the challenges in promoting sustainable forestry is finding ways to connect with these many thousands of landowners. Direct marketing efforts are used to capture the attention of contemporary consumers to advertise diverse products. We used a direct marketing campaign to offer woodland related information to new landowners in three distinct urbanizing zones in West Virginia. We followed the idea of the Ohio Welcome Wagon in this effort.

The West Virginia Woodland Welcome Wagon began reaching out to new woodland owners through a 10 county pilot program. These new landowners were identified through state tax records and contacted via direct mail. An initial mailing, using postcards, was carried out to allow landowners to request a forestry resource information packet as well as be invited to upcoming workshops. This document will address the findings of a follow up survey conducted six months after the initial mailing. 


\section{ACKNOWLEDGEMENTS}

I would first like to thank my advisor, Dave McGill, for his constant support and irreplaceable guidance and patience throughout this study. I would also like to thank my committee members, Dr. Arano and Dr. Owen, for their generous time and contributions. In addition, I would like to thank fellow students and friends for their assistance and support throughout this process. 


\section{TABLE OF CONTENTS}

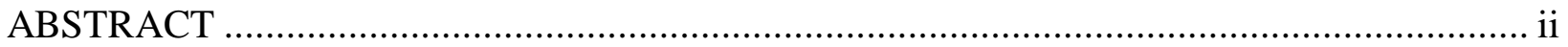

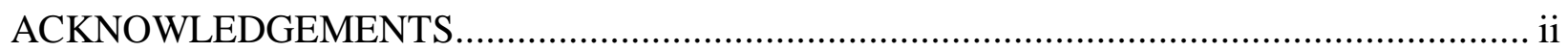

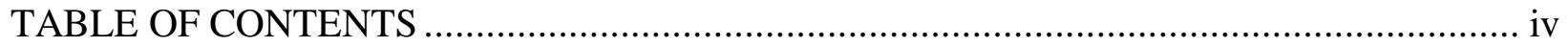

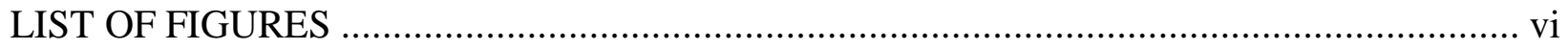

LIST OF TABLES. ....................................................................................... vii

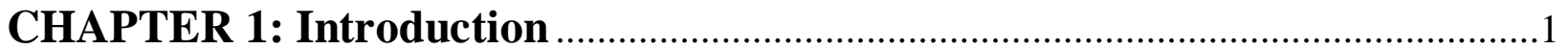

CHAPTER 2: Review of Literature..................................................................

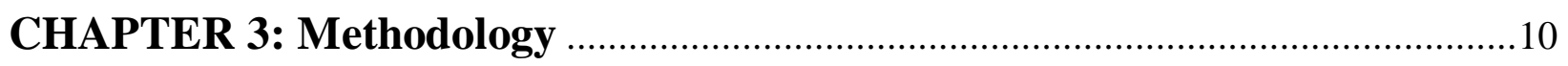

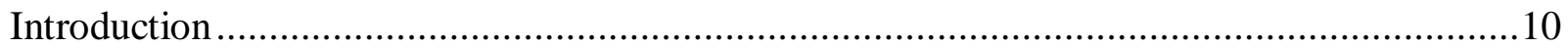

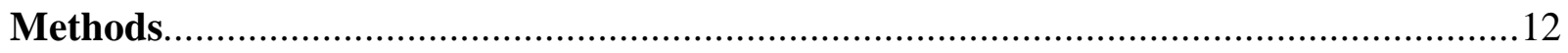

Phase I: Identifying new family forest owners .....................................................

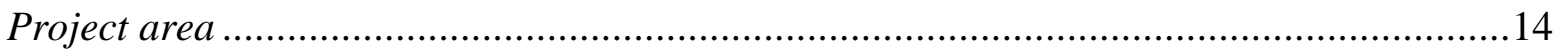

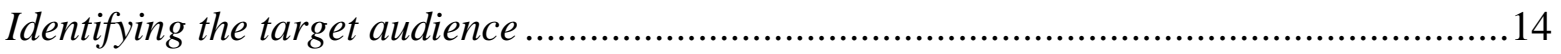

Selecting "new" family forest owners ......................................................................16

Phase II: Contacting WV WWW target audience ....................................................18

Initial contact with new woodland owners ........................................................18

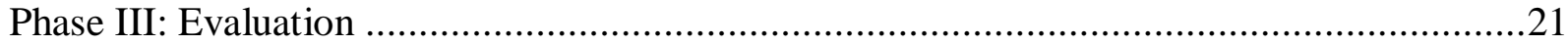

Questionnaire Design and Assessment ...........................................................21

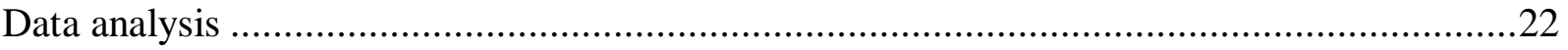

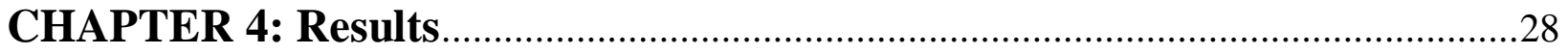

WV Woodland Welcome Wagon Project: Initial Contact..............................................28

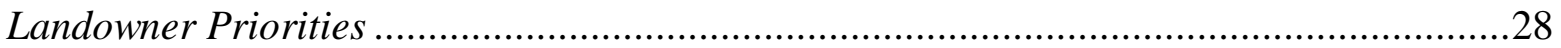

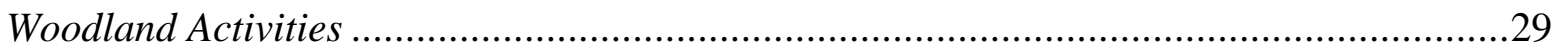

WV Woodland Welcome Wagon Project: Evaluation ................................................229

Questionnaire Results ...................................................................................29

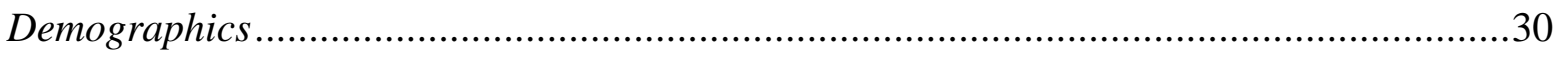

Recollection of WVWWW Program Invitations .......................................................31 


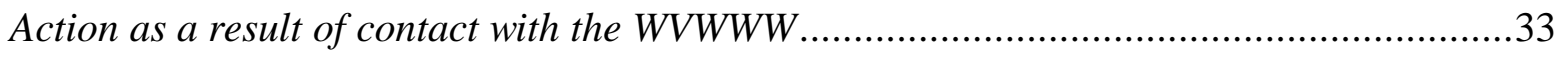

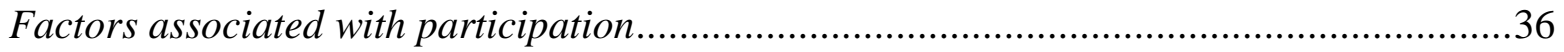

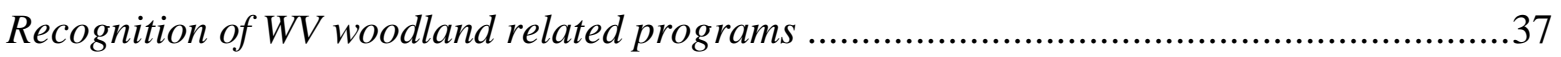

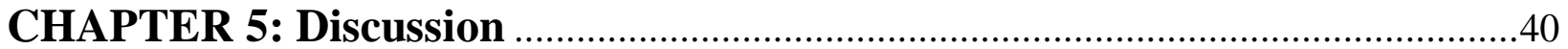

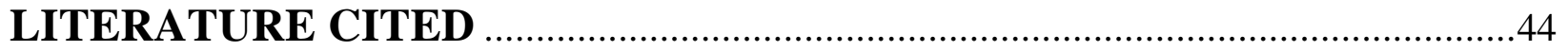

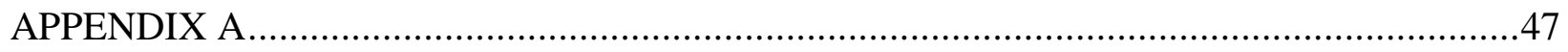

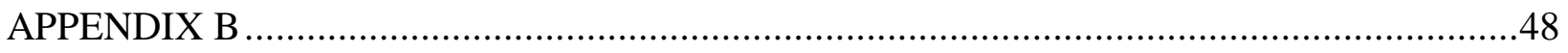

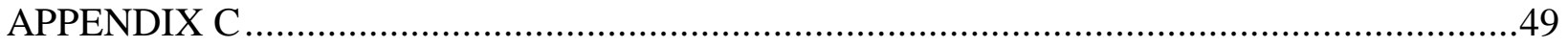

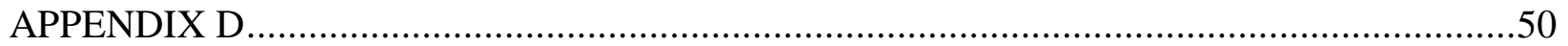

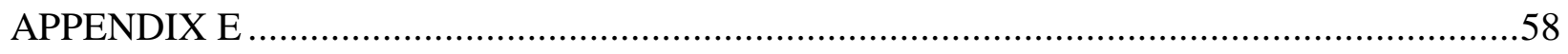

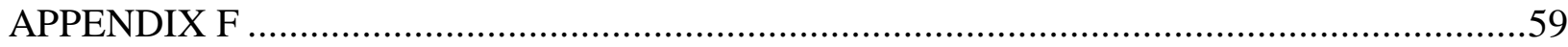

APPENDIX G 


\section{LIST OF FIGURES}

Figure 1. Map of counties included in the three priority areas of the pilot study................20

Figure 2. West Virginia Woodland Welcome Wagon initial contact postcard..................26

Figure 3. West Virginia Woodland Welcome Wagon landowner priorities from initial

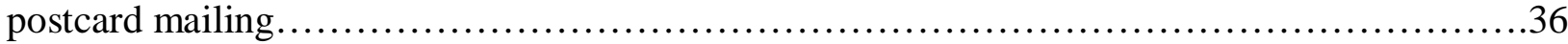

Figure 4. Percentage of respondents recalling the initial WVWWW postcard. Levels of contact are LOW) initial postcard only, MED) initial postcard and informational packet, and HIGH) initial postcard, informational packet, and workshops invitations..........................40

Figure 5. Percentage of woodland owner respondents reporting that they are familiar with various natural resource management organizations, agencies, and programs................45 


\section{LIST OF TABLES}

Table 1. Initial and modified attitudinal categories and classification criteria for segmenting WV woodland owners into categories related to their values associated with owning woodland

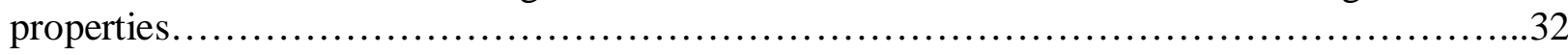

Table 2. Independent variables....................................................

Table 3. Comparison of actual postcard responses to WV WWW invitations with recollections reported in mailed evaluation questionnaire.......................................... 39

Table 4. Number of postcard responses by respective questionnaire responses concerning contact with professional forester..................................................42

Table 5. Number of postcard responses by respective questionnaire responses concerning a written woodland management plan..............................................42

Table 6. Variables associated with West Virginia Woodland Welcome Wagon Participation....44

Table 7. Relationship of contact level and the mean number of woodland related organizations with which respondents indicated familiarity. 


\section{CHAPTER 1}

\section{Introduction}

Over 7 million acres of West Virginia's landscape is in the hands of family forest owners (Widmann, 2012). Family forest owners are defined as families, individuals, trusts, estates, family partnerships, and other unincorporated groups of individuals that own forest land (Butler, 2008). In order to protect and conserve the ecosystem services and products provided by these woodlands, the involvement of this population is essential. With knowledge and forest management information, many woodland owners can improve the overall health, sustainability, and productivity of these lands.

The role of today's natural resource professionals (NRPs) is to promote sustainable forestry practices, and one of the primary challenges in doing this is finding ways to connect with these many thousands of landowners to keep "forests as forests.” The health of the forest ecosystem and the forest industry are heavily impacted by the management activities these landowners implement, yet it has been reported that the majority of private landowners do not have a forest management plan (Butler \& Leatherberry, 2004). Widening the gap between landowners and natural resource professionals is the discrepancy between these two groups on the definition and necessity of forest management (Davis \& Fly, 2010).

In addition, parcelization, which is the division of land into smaller ownership parcels (Gobster \& Rickenbach, 2004), is a large threat to forest land that has been shown to limit forest ecosystem services (Gustafson \& Loehle, 2006; Mehmood \& Zhang, 2001). Increasing land 
taxes, property shifts due to death, and encroaching industry all result in a high risk of parcelization (DeCoster, 1998). With development expanding from the cities and towns of and around West Virginia, this threat is increased (Warner, 2006).

A significant issue that will continue to shape the landscape and contribute to dividing properties is the shift in ownership likely to take place in near future. As nearly 20 percent of West Virginia's family forest owners are over the age of 65, we will see many new landowners arise as these lands are passed on or sold off to new possessors (Widmann et al., 2012). The different goals, backgrounds, characteristics and motivations of these new landowners will impact the future of forestland (Butler, 2008).

With outside influences and the changing of property ownerships, landscape alteration is inescapable. Despite the fact that these individually owned woodlands significantly influence the whole landscape, currently very few direct marketing efforts that promote forestry educational opportunities are focusing on outreach to new landowners.

Contacting this population and linking them with services and organizations that offer support will not only encourage forest conservation but will also help many individuals and families establish their ideal woodlands. The West Virginia Woodland Welcome Wagon is a project established to connect family forest owners with the professional forestry community. This program, modeled after the Ohio Welcome Wagon, seeks to fill an outreach and education niche for West Virginia landowners.

Discussed in this document is the design, implementation, and evaluation of this landowner outreach program. The impacts of this project will be examined and reported and recommendations for further research will be proposed. 


\section{CHAPTER 2}

\section{Review of Literature}

In the eastern United States the majority of the forested land is held by private landowners (Best \& Wayburn, 2001). In West Virginia more than 250,000 families and individuals together own 60 percent of the 12 million acres of forested land (Butler, 2008; Widmann et al., 2012). The health of the forest ecosystem and the forest industry are heavily impacted by the management these landowners perform; the sheer numbers of landowners coupled with their individual goals make the landscape a diverse patchwork of individually managed parcels. The role of today's natural resource professionals (NRPs) is to influence the management of the social, economic and ecological values that are provided by these many individual properties.

Challenging this responsibility are the many changes to the landscape due to ownership turnover, increasing development and higher land taxes (DeCoster, 1998). As a result of these issues, the risk of parcelization and fragmentation of forestland is heightened (Mehmood \& Zhang, 2001). Fragmentation can be defined as forest habitats becoming isolated from one another across landscapes (Mehmood \& Zhang, 2001) and has the potential to decrease forest functionality (Best \& Wayburn, 2001). With parcelization, where a given piece of land is divided into smaller ownership parcels (Block-Torgerson et al., 2010; Gobster \& Rickenbach, 2004; Sagor, 2006) more people own a piece of forest land than ever before (Kittredge, 2004). This division of land puts resources at risk as parcelization has been shown to increase fragmentation, limit recreational access, (Gustafson \& Loehle, 2006) and diminish timberland (Best \&Wayburn, 2001). Forest management in landscapes dominated by private forest owners becomes especially complicated as fragmentation of lands increases (Butler \& Leatherberry, 2004; Sampson \& 
DeCoster, 2000). As property ownership changes, the new landowners are likely to have different motivations (Butler \& Leatherberry, 2004; Rickenbach \& Kittredge, 2009; Salmon et al., 2006). Educational outreach to landowners has become a necessity and more of a challenge than ever before as these current issues impact West Virginia's private lands (Best \& Wayburn, 2001). Though these individually owned woodlands significantly impact the whole landscape (Butler et al., 2007), currently no direct marketing efforts that promote forestry educational opportunities and management information are focusing on outreach to new landowners in West Virginia.

Timber harvesting is a key focus of various states' environmental stewardship programs because this forestry practice can have long-term impacts on the forest and on downstream communities. Moreover, private woodlands are an important source of raw material for the wood-using industry that at times has represented a 4 billion dollar annual infusion into the West Virginia economy (Childs, 2005). With the combination of its financial motivations and long term effects it is no surprise that timber harvesting has long been the focus of natural resource professionals and their research. However, other landowner priorities are equally important, and often outweigh the importance of timber and financial gain (Butler \& Leatherberry, 2004; Butler et al., 2007; Joshi \& Arano, 2006). Landowners are a highly diverse population and equally diverse are their reasons and motivations for owning land (Kendra \& Hull, 2005; Salmon, 2006). Property owners cite other significant objectives, such as recreation, wildlife, and privacy as reasons for owning land. Lifestyle concerns like living simply, naturalism and escapism rank higher than economic concerns (Kendra \& Hull, 2005) according to several woodland owners. Some landowners felt that to "enjoy" and "protect" their land was more important than to "produce” from it (Rickenbach \& Kittredge, 2009). 
This movement of primary motivations from timber to recreation, privacy, enjoyment etc., presents an ongoing trial to natural resource agencies in the promotion of conservation activities that encourage sustainable practices on this diverse forested landscape. There are a growing number of issues for foresters to take into account as management expands to include not just sustainable timber production, but also conservation of ecosystem services. Despite the greater focus on the provision of ecosystem services, landowners still consider their timber a valuable asset. In fact, nearly half of the landowners nationwide have had a timber harvest at some time (Butler \& Leatherberry, 2004), only validating the notion of a diverse population and a need to include several activities in landowner outreach efforts.

As noted, outreach to these family forest owners is important as they supply the public not only with timber, but with recreation opportunities and ecosystem services (Butler \& Leatherberry, 2004). A lack of knowledge and management can reduce the overall health and productivity of the forest and with several barriers and issues challenging the land, connecting with those who own it is vital. Contacting this population and linking them with agencies and organizations that offer support is essential as these individuals and families work in their woodlands. Butler and Leatherberry (2004) report that only 3\% of landowners nationwide have a written management plan, which suggests that a considerable portion of the landowners who sold timber may not be getting the basic and proper guidance during the harvest process.

Natural resource professionals are communicating with landowners, it is just suggested they might not be connecting with the population who needs it most. The forestry community interacts well with the landowners they correspond with regularly. However this group represents what Butler et al. (2007) refer to as a Model Owner, those woodland owners that have sought out help and are likely already knowledgeable. The question is how to reach the much 
larger population that may be unfamiliar with forest management activities. As Davis and Fly (2010) discuss the discrepancy between private forest landowners (PFLs) and NRPs on forest management, it suggests that maybe PFLs don’t know how to manage their land, because many already believe they are. They found that $77 \%$ of those surveyed believed they managed their land, yet many of these landowners also perceive forest management to actually be what was labeled in the study as "property maintenance.” There are a majority of others who admittingly do not manage their land. In a study by Kendra and Hull (2005) it was found that many of the individuals surveyed said they value the quality of the land, but believe they do not know enough about it to manage it. This may be in a large part due to the reality that many landowners do not know where to turn to seek help and information. Joshi and Arano (2006) reported that few landowners, $18 \%$ of those questioned, are aware of the assistance and educational programs that are available in West Virginia. The fact that this important population is unacquainted with information and opportunities poses a real problem. How can we get landowners to make informed decisions regarding their property when we can't seem to successfully connect with them?

To better understand this population of non-industrial private forest owners, many studies have focused on segmentation, or clustering, as a way to represent this diverse group and in turn, better serve them (Kendra \& Hull, 2005; Majumdar et al., 2008; Salmon, 2006). Audience segmentation "refers to the process of dividing a population into distinct segments based on characteristics that influence their responsiveness to marketing interventions” and in turn, help determine the best way to reach each group (Forthofer $\&$ Bryant, 2000). By recognizing that landowners should not be clumped into one homogenous class, priority targets can be identified and outreach to these landowners can be specialized. Majumdar et al. (2008) used this 
segmentation approach by characterizing family forest owners into three groups: multipleobjective, timber and non-timber. They found that almost half of those surveyed in Alabama, Georgia and South Carolina fit into the multiple-objective group, suggesting many landowners value financial benefits as well and non-financial benefits. An audience segmentation of Utah landowners used similar groupings of "amenity-focused, mulptiple-benefit and passive landowners," and found that the majority of landowners in all segments had not harvested timber (Salmon et al., 2006).

Butler et al. (2007) used the clustering method in his social marketing approach to expose types of landowners from which outreach methods can then be tailored. The "attitudinal segmentation" examined reasons for owning land and levels of engagement with it. Based on landowner characteristics, four groups were identified: woodland retreat owners, working the land owners, supplemental income owners and ready to sell owners. Further segmentation was done using a "prime prospect analysis" that looked at individuals levels of engagement and interest with their woodlands. Four additional groups were identified: model owners, prime prospects, potential defectors and write-offs. This study suggests that "model owners" are already doing what needs to be done, and therefore outreach attention should be given to "prime prospects," those that are interested but not currently engaged, and "potential defectors," those that are slightly engaged and are likely to lose interest.

Length of ownership is one of the many attributes used to segment landowners. With parcelization and an increase in the number of forest owners, this attribute may emerge as a significant trait to examine when crafting outreach programs. New landowners will likely have different goals, backgrounds, characteristics and levels of motivations that will shape the future of forest land (Butler, 2008). Joshi and Arano (2009) found that tenured landowners were less 
likely to engage in land management activities. It is important to point out that nearly 20 percent of family forest owners in West Virginia are over the age of 65, potentially generating a shift in land ownership (Widmann, 2012). As ownership is expected to change drastically in the next decade, special attention should be given to these new landowners. Because this population is increasing, outreach to new landowners is imperative and, according to Widmann et al. (2012), it is one of the "issues to watch."

Future forest owners have the potential to positively or negatively influence the landscape (Butler \& Leatherberry, 2004). Acknowledging that collectively these landowners have the power to either improve or to contribute to the deterioration of lands validates the need to connect with this audience. It is suggested that new landowners may be more receptive to messages related to their property and that length of tenure might be a worthwhile variable to consider when designing outreach methods (Rickenbach \& Kittredge, 2009).

If foresters are going to promote sustainable land management, they need make more publicly aware the assistance that is available and connect with forest owners before they act. A study by McGill et al. (2004) revealed that more than half of those surveyed had not received any information on sustainable forestry topics during their recent timber transaction. Salmon et al. (2006) suggest the main responsibility of forest outreach is providing the resources necessary to make these informed decisions. They define "active management" as "informed decision making on the part of the landowners to maximize the benefits they value on their property (even if their decision is to do nothing)."

Several attempts at outreach initiatives are using "social marketing” to get their message through to landowners and make these resources known. Social marketing is defined as "the use of 
commercial marketing techniques to effect positive social change” (Butler et al., 2007). With this approach, the goal is not to sell a product, but to sell a behavior and to implement changes (Kolter \& Zaltman, 1971; Tyson, 1998). The primary objective in reaching out to landowners would be to foster informed decision making. For example, in general, only half of the landowners who harvest timber include a professional forester (Butler et al., 2007). With social marketing, the goal is not to promote timber harvesting, but instead to encourage private landowners to use a professional forester if in fact the landowner decides to harvest timber. After successful segmentation and identification of a specific audience, the ideal outcome of outreach as, Tyson et al. (1998) point out, would be a difference in the behavior of that target audience.

To influence a behavior change in new landowners we will look into an outreach method that strives to connect with this population and offer resources and information that will guide them in forest management. This contact approach was previously conducted by Ohio State University Extension in partnership with Rural Action Sustainable Forestry (Apsley et al., 2005). This program, the West Virginia Woodland Welcome Wagon, will use a direct marketing campaign to deliver material on woodland related information, programs and assistance opportunities. This effort is unique in that it aims to reach new woodland owners in urbanizing zones of West Virginia. 


\section{CHAPTER 3}

\section{Methodology}

\section{Introduction}

Using a Welcome Wagon Approach to Reach New Landowners

The majority of forested land in the eastern United States is owned by private landowners (Best \& Wayburn, 2001). In West Virginia, 60 percent of the 12 million acres of forested land are held by more than 250,000 families and individuals (Butler, 2008; Widmann et al., 2012). Landowners are a highly diverse population and equally diverse are their reasons and motivations for owning land (Kendra \& Hull, 2005; Salmon et al., 2006). Collectively, this group has the potential to positively or negatively influence the landscape (Butler \& Leatherberry, 2004), making them an important population to with which to connect.

Previous studies indicate that private woodland owners lack the confidence or motivation needed to fuel woodland management (Kendra \& Hull, 2005). What is more, a significant number of landowners are unaware of the existence of several forestry-related assistance programs available to them (Joshi \& Arano, 2006).

Finding ways to effectively communicate with landowners has been a challenge for many NRPs. In an attempt to reach more of these diverse woodland owners, several researchers have focused on classifying landowners by characteristics as a way to target specific groups and in turn, to better serve them. For example, Rickenbach and Kittredge (2008) discuss the importance of length or "time" of ownership as an attribute to consider in regards to landowner outreach. In a 
recent study they found that recent arrivals were similar in their landowner motivations. The authors speculate that, because they are new, these landowners might not yet have established plans for their woodland, making them a potentially more receptive audience.

In an effort to connect new private woodland owners with the professional forestry community and the many educational and technical programs available to them, the West Virginia Woodland Welcome Wagon (WVWWW) was established. This contact approach was modeled after the Ohio Welcome Wagon (Apsley et al., 2005) and was modified to include some recommendations generated from that project.

The WVWWW aimed to fill the direct marketing niche for forestry education programs by targeting new landowners. The primary objective was to connect landowners with natural resource professionals who could offer valuable information and technical support on forest management for landowners. The West Virginia Woodland Welcome Wagon operated as the vehicle in which information about forestry and natural resources agencies, services, and organizations was distributed to property owners.

The procedure for the WVWWW was carried out in a three-phase project that focused on ten counties where urbanization is prominent. The first phase of the project was identifying the target audience of new landowners who have acquired ten acres or more of woodland within the past year (2009-2010). The second phase focused on contact and outreach accomplished through a series of direct mailings. The third and final phase was a follow up survey conducted six months after initial contact. The survey inquired about behavior changes of the landowner since being contacted by the WVWWW and sought to answer questions about the variety of private forest landowners within the state of West Virginia. 


\section{Methods}

The WVWWW is a three-phase project that focuses on ten counties in West Virginia where urbanization is prominent. The three primary areas are the Eastern Panhandle, a prime commuter location, (Berkeley, Jefferson, Morgan), the Technology Corridor (Monongalia, Harrison, Marion) and the highly developed Metro Valley (Putnam, Kanawha, Cabell, Lincoln) (Figure 1).

The first phase of the project was simply identifying new landowners in these counties who have acquired ten acres or more of woodland within the past one to two years. The second phase was to contact and conduct outreach through direct postcard mailings giving landowners the opportunity to request woodland related resources. Phase three, the evaluation phase, was conducted through a follow up survey. 


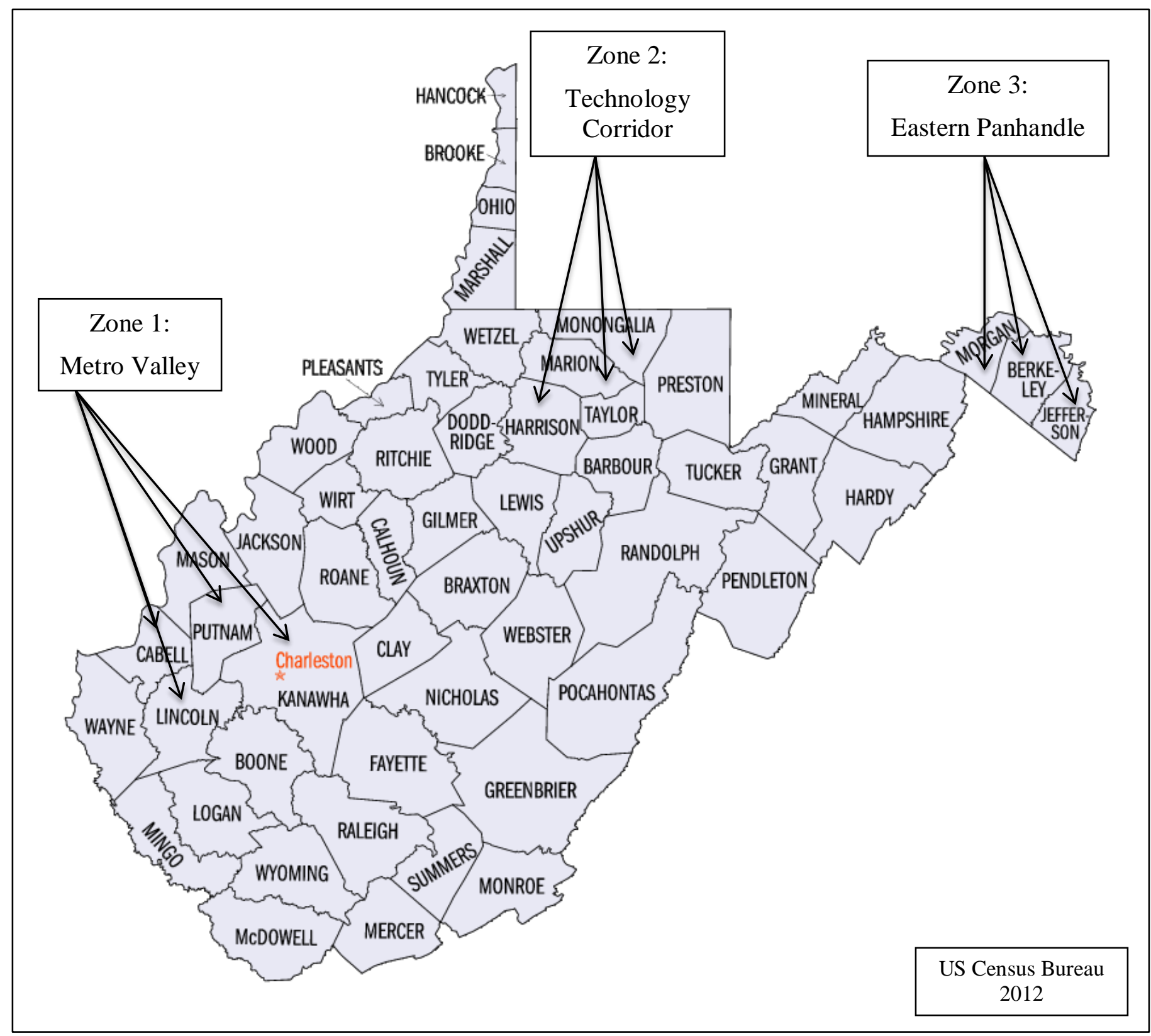

Figure 1. Map of counties within the three priority zones. Zone 1: Metro Valley; Zone 2: Technology Corridor; Zone 3: Eastern Panhandle. 


\section{Phase I: Identifying new family forest owners}

\section{Project area}

This project focused on three priority areas in West Virginia to achieve the primary goal of evaluating the Welcome Wagon approach as a means to connect new woodland owners with peers, professionals, and natural resources agencies. The WVWWW was set up as a pilot program using a small set of priority areas in the state: the Eastern Panhandle, the CharlestonHuntingdon corridor, and the Morgantown-Clarksburg high tech corridor. These three areas are comprised of ten counties and were chosen due to the unique attributes found in their surrounding landscapes. The eastern panhandle has burgeoning development and serves as a bedroom community for people working as far as Washington, DC. The CharlestonHuntingdon corridor is a well-developed area with the state's political infrastructure in close view. Between Morgantown and Clarksburg, high-tech industrial development and associated urban development has accelerated in the past five years. Other areas in the state were planned to be added to the program following this initial outreach effort if this initial pilot effort proved fruitful.

Identifying the target audience

West Virginia county courthouse personnel were either contacted or visited in October 2010 to explore the most efficient way to access addresses of new property owners in the ten counties of the project’s three areas. Specifically, the population demographic selected for this educational outreach project was a family forest landowner who acquired ten acres of land or more within the past 1-2 years. Family forest owners include properties not held by government, corporations or forest products manufacturing firms (Butler \& Leatherberry, 2004). 
County clerks' offices contained property information in deed books and additionally, some counties had an electronic database. In the visits made to three of these county courthouses, their deed books typically lacked crucial information that was necessary to identify new landowners in a straightforward manner. In the case of a property transfer, while parcel numbers were always present, the name and address of the new landowner were rarely included. Harrison County, one of the counties with an electronic database, was visited to explore this method of organizing records. This system held a great deal of information, however, it did not include the date of the transfer, a key point in identifying only the new landowners.

From the visits to county courthouses, it was discovered that most of the state property tax records could be purchased. State tax records from 2009 and 2010 (with the new year beginning on July $1^{\text {st }}$ ) were purchased from the West Virginia State Tax Department for all counties except Kanawha. The tax records were filtered to include only those who owned ten or more woodland acres. Similar to the electronic database of Harrison County, these tax records held all of the necessary information except for the date of purchase. Still unable to decipher between those landowners that recently purchased land from those who have owned for some time, a query was run in Excel that "subtracted" the 2009 database from the 2010 using the map and parcel numbers (the only consistent attributes from year to year) to match properties between the two databases. The names that appeared only in 2010 but had not been present in 2009 were assumed to be the new landowners. This process was carried out for nine of the ten counties; Kanawha County was the exception as it is the only county that manages their own tax reporting to the state. Kanawha County's information was not purchased, but rather obtained with the help from administrators at the Kanawha County Courthouse. A query was run from their office and the final product was a list of names and addresses filling all of the requested attributes. 


\section{Selecting "new" family forest owners}

The first step in obtaining a list of names was to import the state property records in the form of text files into Excel worksheets. Map and parcel numbers (an identification number given to each piece of land) and the name of the landowner were matched between years. If the owner name attached to a given property remained unchanged between 2009 and 2010, it was deleted, as this piece of land had not been transferred. Concerned with contacting only new family forest owners, names were only put on the prospective list if the name in 2010 was different from the name in 2009, signifying a change in property ownership. The list of accumulated landowners from 2010 was then sorted and checked for redundant names and names that did not match our target demographic (new landowners). This list of properties was filtered by assigning a code number to designate the apparent type of transfer which would help identify properties owned by our target audience.

$\mathrm{x}=$ No change

$1=$ Corporate to Private

$2=$ Private to Corporate

3 = Same Family, Different First Names

4 = Private to Private

$5=$ LLC to Private/Private to LLC

$6=$ LLC to LLC

7 = Corporate to Corporate

An " $x$ " was given to those names that were actually the same but had not been picked up in the query due to some minor difference. Such names were deleted and were not used in the final contact list. An example of this is:

John R Smith

John Robert Smith 
Entries were also removed in cases where one name stayed the same throughout both years but an additional name was added or removed. If they were once paired and most recently were not, it was assumed the consistently present individual was not a new landowner. Some reasons for this may be from marriages, divorces or deaths in the family. Though the importance of these intra-generational changes was acknowledged, the goal of this study was to seek out new landowners and therefore these names were removed. An example of this is:

John Smith J John \& Jane Smith

However, in an instance where the first name changed but the last name remained the same (3), these individuals stayed on the list as this was most likely due to inheritance or the buying/selling between siblings. Because the individual to whom the land was transferred may in fact be a new landowner, they were included in the final contact list.

John Smith Sr. $\quad$ James Smith

Private-to-corporate (2) and corporate-to-corporate (7) transfers were also discarded as the focus of this study was on family forest owners, not businesses. For this same reason, if an LLC was involved whose name sounded like a company, this address was not recorded. An example of this is:

John Smith ABC Homes LLC

One limitation of this selection process is that it may produce some bias in the data as not all corporate sounding names are in fact corporate businesses and not all names that sound like private individuals are individuals (possible to have a big business with a family name). Transfers to private individuals, codes 1, 3, 4 and some 6 , were recorded and used for the final 
contact list.

\title{
Phase II: Contacting WV WWW target audience
}

\author{
Initial contact with new woodland owners
}

The final list generated for this WVWWW pilot study contained 900 new landowners in the tencounty area. These 900 addresses make up the WVWWW target audience. The next step was to contact these landowners and offer a woodland information packet intended to provide some forestry-related materials to new landowners.

Initial contact was a mailing sent out on May 6, 2011 to the 900 WVWWW addresses. Included was a cover letter describing the goal of the project and a postage-paid postcard designed to gain information from the landowners and to serve as a vehicle with which they opted in or out of this education outreach program. The welcome letter (Appendix A) explained the objectives of the West Virginia Woodland Welcome Wagon and the reason for and how to use the postcard. On the postcard was a code number assigned to each name to assure confidentiality on returned postcards.

The first statement on the card (Figure 2) allowed the recipient to check whether they would like a packet containing woodland related information and whether or not they would like to be invited to upcoming workshops. They also had the option to check "No thanks, I am not interested”. In addition to these statements intended to establish contact, there were questions designed to learn more about this population of new landowners. Questions were related to previous contact with a professional forester, whether the landowner had a written forest stewardship plan, and if they currently lived on this woodland property. Finally, at the bottom of 
the card was a place for the landowners to rank priorities that he or she had for their woodland.

\section{Get Connected!... To the WV Woodland Welcome Wagon}

Return this postcard to access professional information about working in your woodlands. (Check all that apply)

$\square$ Yes, please send me the general woodland information packet.

$\square$ Yes, please invite me to upcoming woodland-related workshops.

No thanks, I am not interested.

If you have a minute, we'd like to know about your woodland activities.

$\square$ Yes $\square$ No I have a written plan for my woodlands.

$\square$ Yes $\square$ No I have contacted a professional forester about my woodlands.

$\square$ Yes $\square$ No Do you live on your woodland property?

Rank the priorities you have for your woodland property? (1=highest priority)

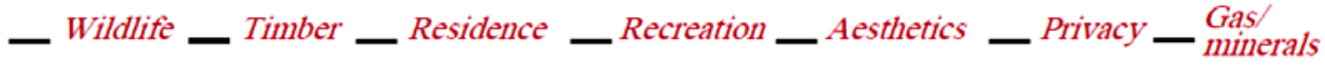

Figure 2. West Virginia Woodland Welcome Wagon initial contact postcard.

As postcards were returned, all information was entered into an Excel spreadsheet. A packet was sent out to those landowners that requested one and if they asked to be invited to upcoming events their name was added to a mailing list. The forest resource packet consisted of a welcome letter (Appendix B) and information on the following:

- WV Forest Stewardship Program

- WV Woodland Owners Association

- WV Forestry Association

- WV Christmas Tree Growers Association

- Guide to Choosing a Forester

- Managed Timberland Tax Program

- Call Before you Cut booklet

- Contact numbers for county extension agents 
- Quality Deer Management Association

- WV Woodland Stewards webpage

On June $21^{\text {st }} 2011$, a second mailing of a welcome letter (Appendix C) and postcard was sent out to all of the non-respondents. As with the first mailing, as the postcards were returned all data was entered and packets were sent out accordingly.

Throughout the summer and fall of 2011, invitations in the form of postcards were sent to WVWWW participants inviting them to woodland related events and workshops all across the state of West Virginia. From June 2011 to November 2011, ten different events or workshops were held including a series called "meet your forester" which was offered at six different times and locations, twice in each of the three priority pilot areas. This workshop was geared toward new landowners and any others who were interested in learning about types of foresters and how they can assist woodland owners.

The target population of 900 woodland owners had various levels of contact with the WVWWW project depending on their postcard response. Those who did not return a postcard or replied "no thanks,” received no further contacts. Those requesting a packet only received the packet but no subsequent contacts; hence two contacts including the initial postcard and the informational packet. Postcard respondents asking for both the packet and to be invited to upcoming workshops received at least three contacts: the initial postcard, informational packet, and invitations (up to ten) to various woodland-related workshops and seminars. Level of contact was coded into three discrete categories: 1) initial postcard only, 2) postcard and packet, 3) postcard and workshop invitations. 


\section{Phase III: Evaluation}

\section{Questionnaire Design and Assessment}

A mailed questionnaire (Appendix D) was developed to evaluate the impact of the WV Woodland Welcome Wagon. This survey, based on the Dillman (2000) Tailored Design Method, was created as part of a larger study to assess connections between neighboring landowners. A section within this questionnaire was devoted to measuring the impacts of the earlier Welcome Wagon study. This survey was sent to a review panel of two WVU faculty member and two private woodland owners.

The questions included in the survey inquired about possible behavior changes as a result of contact with the WVWWW. Postcard recollection and response was a primary item for evaluation on the questionnaire. Questions inquired about whether or not the respondents recalled getting a postcard from the WVWWW project. If the answer was yes, the questionnaire asked for details on how they responded and what type of action was taken as a result of contact. Other questions asked about whether or not they have attended a workshop within the last nine months or if they are familiar with certain woodland related programs (ones that were included in the packet).

The questionnaire was sent out to the original 900 WV WWW participants on January 23, 2012 following a pre-survey postcard (Appendix E) that was sent on January 17th. As with the initial postcard, each survey contained a code number that corresponded with a name to ensure confidentiality of those who returned questionnaires. Included with the survey was a postagepaid return envelope and a cover letter (Appendix F) explaining the survey. A reminder postcard (Appendix G) was sent out two weeks later and a second mailing of the questionnaire was sent out on February 15, 2012 to those who had not yet responded. 
As questionnaires were sent back, all data was entered into an Excel spreadsheet. For analysis purposes, a cutoff date was set and questionnaires received after April 11, 2012 are not included in the results.

\section{Data analysis}

Two primary questions related to participation and program impact were explored as a means of evaluating the effectiveness of the WVWWW.

Evaluation question 1 (EQ1): What woodland owner attributes, if any, were associated with respondents’ participation level, and

Evaluation question 2 (EQ2): What impacts or changes in behavior or practices could be linked to their participation with the program.

The original list of 900 WVWWW contacts was categorized into participants and nonparticipants. This classification was used as a binary dependent variable (participant/nonparticipant) in logistic regression to explore the factors associated with participation (EQ1).

EQ2 explored impacts associated with the WVWWW project. Dependent variables representing changes made by respondents between the initial contact and the questionnaire period (approximately six months) included contacting a forester or developing a written plan.

Independent variables used in EQ1 and EQ2 assessments are listed in Table 1. In addition to the variables in Table 1, a variable called "level of contact" was also included as a factor associated with participation. Participants had either requested an informational packet, or requested both a packet and to be invited to workshops. Hence respondents were classified into low (LOW), medium (MED), and high (HIGH) levels of contact (LOC) with the WVWWW: 
a) LOW-this category included individuals who had received the initial invitation postcard, but had either responded that they did not want to participate or had simply not responded,

b) MED—was made up of those individuals who requested the informational packet, but not the invitations to workshops, and

c) HIGH - the category containing the individuals who asked for the informational packet and to be invited to workshops.

LOC was used as an independent variable along with others in EQ2 to evaluate determinants of program impacts. Other independent variables used in this assessment were: demographic variables, management-related variables, tenure time and residency, and certain social indicator variables (Table 1). These independent variables were selected based on other studies found to be important indicators in explaining landowner motivations (Allred 2011; Joshi \& Arano 2008; Rickenbach \& Kittredge 2009). To test the financial aspect, a variable indicating whether or not they were likely to sell timber (SELL) and in addition, the variable of supplemental income based on the survey question, I generate income from my land or own it for financial investment purposes (INCOME; Butler, personal communication, February 2012). We also considered social factors including to "socialize/discuss," "tour one another’s woodland” and "build a woodland owner network.”

The questionnaire contained a section designed to segment the population of respondents into groups with similar attitudes. A five-part request was posed to elicit values that the respondents held with respect to the reasons for owning their woodland properties. Attitude categories reflected those proposed in a recent market segmentation investigation (Butler et al. 2007). The questions that were used to derive attitude categories in Butler et al. (2007) were received from 
B. Butler (personal communication, 2012), and except for the alphanumeric characters used to identify the specific value statements below (financial, scenery, privacy, recreation, involvement) were incorporated into the questionnaire as follows:

Express how you relate to the following statements. Use a 1 to 10 point scale, with $\mathbf{1 0}$ meaning it describes you completely and $\mathbf{1}$ meaning it doesn't describe you at all.

A.__ I generate income from my land or own it for financial investment purposes

B.__ I own my land for the enjoyment of the scenery

C.__ I own my land for the privacy it affords

D.__ I use my land for recreation purposes

E.__ I'm not particularly involved with my land

Using the attitude classification criterion (above), most respondents were classified into one of the four categories (Table 2). However, half (50\%) of respondents fell outside of these categories and were not classified using the initial criteria. Class ratings by individual respondents were visually inspected to assess the loopholes in the classification scheme. Modified criteria were specified to match as closely as possible to the original classification scheme, but in a way that most of the observations would be sorted into a category (Table 1). One modification was made to the Woodland Retreat class so that the scenery and privacy value statements would only have to be greater than the financial and uninvolved statements, and hence could have equal values with the recreation statement. Another modification was made to relax the Working the Land category criteria to assure that financial was greatest, but to allow more variation in the scenery, privacy, and recreation statement levels. The resulting classification scheme necessarily included two new categories, one labeled as "low values" where respondents reported no value statement as being greater than a "5". An "other" category was used to take all of the remaining special cases. 
Table 1. Factors associated with participation. Independent variables used with binary dependent variable, participant/non participant.

Variables

\section{Owner characteristics}

AGE

EDU

GENDER

INCOME

TENURE TIME

RESIDENCY

TOTAL ACREAGE

GEOGRAPHIC ZONE

\section{Management characteristics}

SELL

FINANCIAL

WOODLAND RETREAT

Social characteristics

SOCIALIZE

NETWORK

TOUR

\section{Definitions}

Age in years $(1=61-70+$ yrs., $0=18-60$ yrs.)

1=some college -Ph.D., $0=$ some high school -some college

$1=$ male, $0=$ female

$1=$ income $>\$ 60,001,0=$ income $<\$ 60,000$

3 states, new/new, new/long, long/long (most recent property/first property)

$1=$ resident, $0=$ absentee landowner

$1=1-50,0=51+$

1= Metro Valley, 2=Technology Corridor, 3=Eastern

Panhandle

Likelihood of selling timber in 10 years $(1=$ very or somewhat likely, $0=$ not likely or don't know)

Binary variable from the attitudinal segmentation $(1=$ supplemental income, $0=$ otherwise)

Binary variable from the attitudinal segmentation ( $1=$ woodland retreat, $0=$ otherwise)

Interest in socializing ( $1=$ interested, $0=$ not interested)

Interest in building a network ( $1=$ interested, $0=$ not interested

Interest in touring another's woodland ( 1 =interested, $0=$ not interested 
Table 2. Initial and modified attitudinal categories and classification criteria for segmenting WV woodland owners into categories related to their values associated with owning woodland properties.

\begin{tabular}{|c|c|c|}
\hline Attitudinal Category & Initial criteria & Modified criteria \\
\hline $\begin{array}{l}\text { Supplementary } \\
\text { Income }\end{array}$ & (A) is highest & (A) is highest \\
\hline Woodland Retreat & (B) or (C) is highest & $\begin{array}{l}\text { (B) or }(C) \text { is higher than }(A) \\
\text { and }(E)\end{array}$ \\
\hline Working the land & $\begin{array}{l}(\mathrm{A}),(\mathrm{B}),(\mathrm{C}) \text { and }(\mathrm{D}) \text { are all } \\
\text { rated highly and about tied } \\
\text { (scores of } 7-10, \text { within a } \\
\text { point of each other) }\end{array}$ & $\begin{array}{l}\text { If }(A)>7 \text { and the sum of }(B \text {, } \\
C \text {, and } D) \text { were }>21\end{array}$ \\
\hline Uninvolved & (E) is highest & (E) is highest \\
\hline Low values & * & If $(A, B, C, D, E)$ all $<7$ \\
\hline Other & * & All others \\
\hline
\end{tabular}

The questionnaire also asked respondents in what year they acquired their most recent woodland property and in what year they acquired their first property. From responses, the variable "tenure time” is divided into three states:

a) New/New- where the most recent property, property acquired within the past five years, is the same as the first property, making this group the "new” landowners.

b) New/Long- woodland owners who are tenured, having owned land for more than five years, yet have also recently acquired a new property.

c) Long/Long- this group of woodland owners have owned their land for at least five years or more and do not have a recent acquisition. 
SAS (SAS, 2000-2004) was used to explore relationships between dependent variables representing changes in woodland owner behavior or practices and demographic and other ownership attributes. PROC GLM and PROC LOGISTIC were used to assess potential associations among dependent and independent variables. Significance levels were set at $\alpha=0.05$ for hypothesis testing. 


\section{CHAPTER 4}

\section{Results}

The WV Woodland Welcome Wagon project had an initial contact list of 900 "new” woodland owners in the ten county priority areas. The evaluation phase for this project used this same list with the intent to document project impacts.

\section{WV Woodland Welcome Wagon Project: Initial Contact}

Of the 900 postcards that were sent out inviting new landowners to request a forestry related information packet, a total of 218 postcards were returned. Of that original list, three were deemed ineligible, reducing the sample size to 897 and generating a $24 \%$ response rate and a cooperation rate of $86 \%$. The number of respondents that requested and were mailed a packet was 187, and 108 of those individuals also requested to be invited to upcoming workshops.

\section{Landowner Priorities}

The postcard recipients were asked to rank priorities for their woodland property with “7” being the highest priority and " 1 ” being the lowest priority. "Wildlife” was chosen as the highest priority of those that responded with a mean rank of 4.7 (Figure 3). The least important objective was “Gas and Minerals” which was given a mean rank of 1.5. 


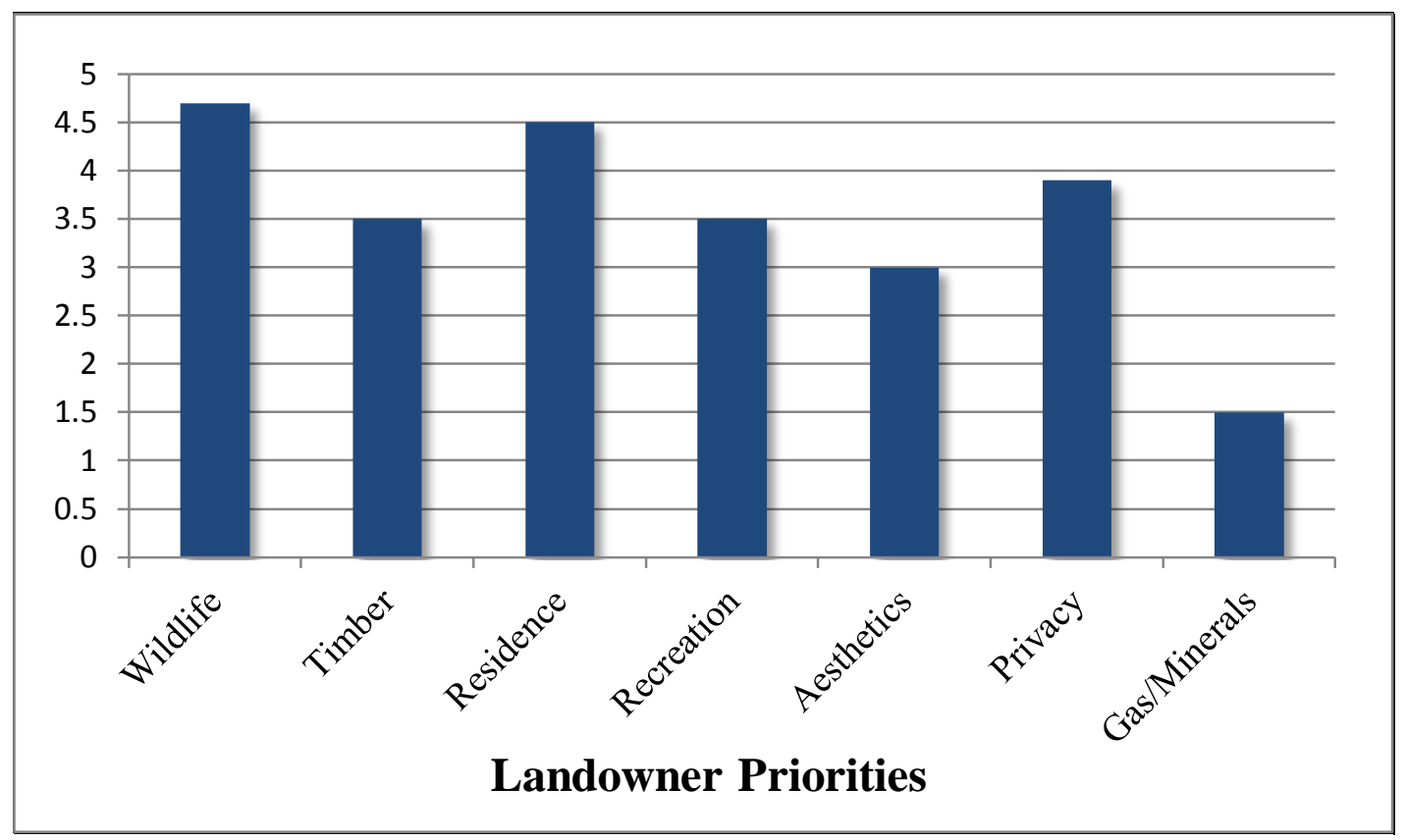

Figure 3: West Virginia Woodland Welcome Wagon landowner priorities from initial postcard mailing. 7=highest priority; 1=lowest priority.

\section{Woodland Activities}

Of those that responded, only 13 individuals currently had a written management plan.

Professional foresters had been contacted by 23 respondents. One hundred and four individuals reported living on their woodland property.

\section{WV Woodland Welcome Wagon Project: Evaluation}

\section{Questionnaire Results}

Of the 900 questionnaires that were mailed to the original Welcome Wagon list, 30 were removed due to ineligibility, reducing the sample size to 870 . Two hundred and four were returned and classified as "complete" questionnaires producing a response rate of $24 \%$ and a cooperation rate of $82 \%$. To address the issue of a non-response bias we followed the procedure 
outlined by Linder et al. (2001). Using the concept that non-responders are similar to late responders, this method suggests comparing early and late responders by variables of interest. We selected 3 variables to represent the range of questions answered by respondents; a landowner attribute variable, a demographic variable and a property attribute variable. No statistical difference was found between variables and therefore these findings can be generalized to the target population. The results of the chi-square test indicate that the variable "length of ownership” for late responders was not significantly different from that of early responders ( $\left.\mathrm{n}=190 ; \chi^{2}=1.5125 ; \mathrm{p}=0.4694\right)$. There was also no significant difference found between early and late responders with the variable "gender" $\left(n=200, \chi^{2}=0.3428 ; p=0.5415\right)$. The variable “total acres” was tested between response time using one-factor (response period) analysis of variance and also found no significant difference between the two groups ( $\mathrm{n}=187, \mathrm{p}=0.6466$ ).

\section{Demographics}

Over half of the respondents (55\%) were between 50 and 70 years of age. Seventy-four percent of those who responded were male. West Virginia forest owners are an educated group with $67 \%$ of owners having at least some college education and nearly $50 \%$ having completed at least a Bachelor's degree. Average yearly income for one third (33\%) of respondents was reported at $\$ 90,000+$ and only $6 \%$ reported a salary below $\$ 15,000$. Of those that reported an occupation, $31 \%$ of respondents were retired. Of those who are currently working, a wide range of occupations were cited including teachers, business owners, coal miners, medical workers and farmers. It was found that the majority (70\%) of those who responded acquired their land through outright purchase. Inheritance was the second most common way of land acquisition, though very far behind, at $17 \%$. 
Landowners were placed in one of three categories; new, long-term, or long-term with a recent acquisition. Less than half (42\%) of the landowners were in fact new and first time woodland owners (new/new) who had acquired their land within the past five years. Thirty-seven percent of respondents were tenured landowners having owned their land for more than five years (long/long). Those individuals who were not first time landowners but who had recently acquired new property (new/long) accounted for $21 \%$ of the respondents.

\section{Recollection of WVWWW Program Invitations}

Despite the fact that the WVWWW population of 900 woodland owners received both an initial invitational postcard and an evaluation questionnaire, questionnaire responses showed a great discrepancy with the results of the initial WVWWW postcard mailing. Of the questionnaire respondents who answered Question \#40, Within the past year have you received a postcard from the WV Woodland Welcome Wagon Project?, over two-thirds (n=133) did not remember receiving the WVWWW postcard (Table 3). Whether or not questionnaire respondents recalled being invited to participate in the WVWWW program was related to their respective levels of contact (Figure 4). Logistic regression with the binary remember/do not remember dependent variable was statistically related to level of contact (Odds ratio $=3.42 ; \chi^{2}=6.819 ; \mathrm{p}=0.009$ ). Hence those who were sent the initial postcard, the informational packet, and workshop invitations (HIGH) were more likely to have recalled the initial postcard from the WVWWW project than those who did not want to participate or did not respond (LOW). There was no statistical difference in recall of the WVWWW initial postcard between nonparticipants (LOW) and those who had received the informational packet only (MED) (Odds ratio=1.90; $\chi^{2}=0.006$; $\mathrm{p}=0.937)$. 
Affirmative responses to both the WVWWW postcard and the evaluation questionnaire were made by 99 woodland owners. Others responded to only one or the other contacts. One hundred nineteen woodland owners signed up at some level for the WVWWW program but did not complete an evaluation questionnaire. Similarly, questionnaires were sent back completed by 105 woodland owners who were not MED or HIGH level participants of the WVWWW.

Table 3. Comparison of actual postcard responses to WV WWW invitations with recollections reported in mailed evaluation questionnaire. Time difference between mailed postcard invitation and evaluation questionnaire was 6 months. The 900 evaluation questionnaires were sent to the same respondents as the postcard invitations.

\begin{tabular}{|c|c|c|c|c|c|}
\hline \multirow{2}{*}{$\begin{array}{l}\text { Evaluation } \\
\text { questionnaire: } \\
\text { Did you receive a } \\
\text { postcard? }\end{array}$} & \multicolumn{4}{|c|}{ Number of postcard responses } & \multirow[b]{2}{*}{ Total } \\
\hline & No thanks & $\begin{array}{c}\text { Send } \\
\text { packet } \\
\text { only }\end{array}$ & $\begin{array}{c}\text { Send } \\
\text { packet and } \\
\text { invite }\end{array}$ & $\begin{array}{c}\text { No } \\
\text { postcard } \\
\text { Returned } \\
\end{array}$ & \\
\hline & \multicolumn{4}{|c|}{---------------------Answered Q40---------------------- } & \\
\hline No & 6 & 24 & 26 & 77 & 133 \\
\hline Yes & 0 & 12 & 24 & 22 & 58 \\
\hline \multirow[t]{2}{*}{ I don’t know } & 1 & 1 & 1 & 1 & 4 \\
\hline & \multicolumn{4}{|c|}{ 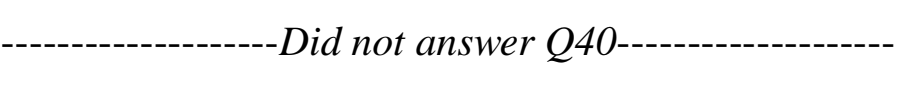 } & \\
\hline No answer ${ }^{1}$ & 0 & 1 & 3 & 5 & 9 \\
\hline Non response $^{2}$ & 24 & 41 & 54 & 577 & 696 \\
\hline Total & 31 & 79 & 108 & 682 & 900 \\
\hline
\end{tabular}




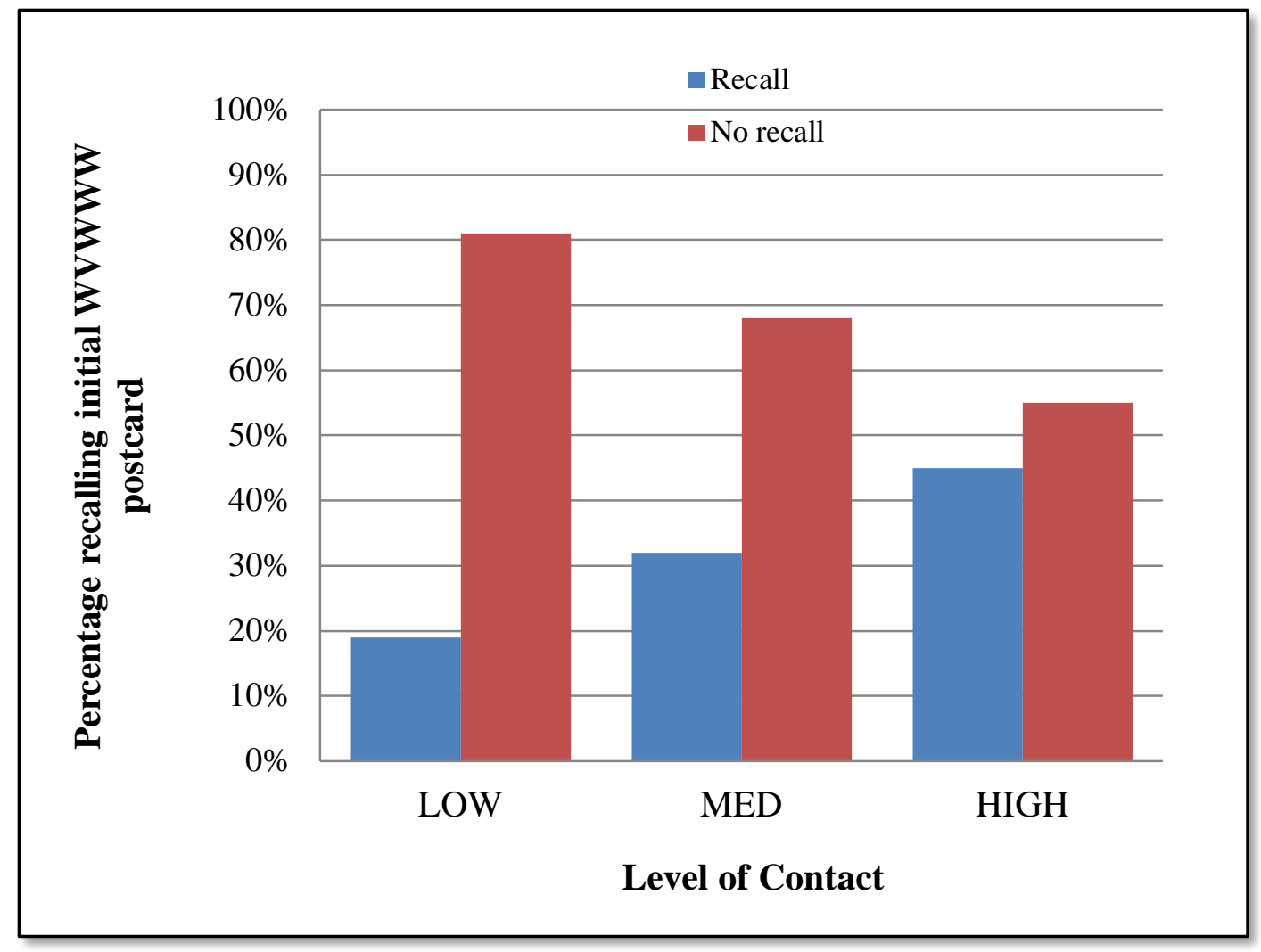

Figure 4. Percentage of respondents recalling the initial WVWWW postcard. Levels of contact are LOW) initial postcard only, MED) initial postcard and informational packet, and HIGH) initial postcard, informational packet, and workshops invitations.

\section{Action as a result of contact with the WVWWW}

In addition to being asked if they had received a postcard from the WVWWW, questionnaire respondents were asked about any actions taken since participating in the project. One participant reported an action associated with the WWW program. The single respondent attended two workshops as a result of being sent direct invitations through the mail. Two respondents noted their interest, but commented on having time and date conflicts with the scheduled workshops. When asked what the participants found to be most helpful, one respondent stated, “info on the programs available,” and another reported, "wildlife 
management.” One participant responded “I didn’t get a chance to look yet” and all other responses (23) to the questions pertaining to "action" and "most helpful” were either "no" or "I don’t remember.”

Other indicators of impacts from this project are whether or not since receiving a packet the participants contacted a professional forester or developed a written management plan. Eightyeight WVWWW participants filled out the question concerning whether they have made contacts with professional foresters on both the postcard and the evaluation questionnaire. Most (61) were consistent in their responses that they had not contacted a professional forester, neither at the time of the initial WVWWW postcard or six months later on the evaluation questionnaire (Table 4). However, nine woodland owners who indicated they had no contact with a professional forester on the initial postcard, responded six months later on the questionnaire that they had indeed contacted a forester. Each of these nine respondents were WVWWW participants that were sent an information packet; seven of the nine were HIGH contact participants receiving both a packet and workshop invitations. It is important to note, however, that this change in forester contact cannot be directly attributed to contact with the WVWWW project because of the lack of non-WVWWW participants filling out the initial postcard. Only four people that filled out a postcard, yet indicated that they did not want to participate in the WVWWW, also filled out an evaluation questionnaire. Of these four, none of them had contacted a forester prior to or during the project period.

Another measure of potential impact is whether participating in the WVWWW led participants to develop a written forest management plan. The majority of respondents (67) replied on both the initial postcard and on the questionnaire that they did not have a written plan for their woodlands (Table 5). Interestingly, three participants who indicated on the postcard that they did 
not have a written management, revealed that at the time of the questionnaire they did in fact develop a written plan. Two of these participants were HIGH levels of contact, the other MED. As with "forester contact” this change cannot directly credit the WVWWW project due to lack of details and lack on of non-WVWWW participants filling out the postcard.

Table 4. Number of postcard responses by respective questionnaire responses 6 months later concerning contact with professional forester.

\begin{tabular}{|c|c|c|c|c|}
\hline \multicolumn{5}{|c|}{-------Postcard response------- } \\
\hline $\begin{array}{l}\text { Questionnaire } \\
\text { response }\end{array}$ & No forester & Forester & $\begin{array}{c}\text { No } \\
\text { answer }\end{array}$ & Total \\
\hline No forester & 61 & 2 & 11 & 74 \\
\hline Forester & 9 & 9 & 3 & 21 \\
\hline Total & 70 & 11 & 14 & 95 \\
\hline
\end{tabular}

Table 5. Number of postcard responses by respective questionnaire responses 6 months later concerning a written woodland management plan.

\begin{tabular}{|c|c|c|c|}
\hline \multirow[b]{2}{*}{ Questionnaire response } & \multicolumn{2}{|c|}{---Postcard response--- } & \multirow[b]{2}{*}{ Total } \\
\hline & No plan & Plan & \\
\hline Yes & 3 & 7 & 10 \\
\hline No & 67 & 1 & 68 \\
\hline I don't know & 3 & 1 & 4 \\
\hline $\begin{array}{l}\text { I have contacted a forester but do } \\
\text { not have plan yet }\end{array}$ & 2 & 0 & 2 \\
\hline Total & 75 & 9 & 84 \\
\hline
\end{tabular}


In response to the question have you attended a woodland related workshop since May 2011, 6 (11\%) participants said "yes.” Level of contact was statistically associated with this variable with the 6 participants having the highest level of contact (HIGH) with the WVWWW (Fisher's Exact Test; n=200; $\mathrm{p}<0.0003$ ); MED and LOW contact participants did not attend any workshops in the past six months. While only respondents from the HIGH contact category indicated having attended a workshop, there were no further details in the questionnaire to allow us to be certain that this was a direct result of the WVWWW invitations.

Finally, while not part of the questionnaire, one participant signed up for the online WV Stewards social network after being sent a packet.

\section{Factors associated with participation}

Based on determinants used in other studies, 15 independent variables were chosen as potential participation indicators from the survey (Table 1). Some of the variables were found to be highly correlated and were removed to avoid multicollinearity. To discover which of these landowner attributes, if any, were indicators of reasons why WVWWW participants requested information (EQ1), a logistic regression procedure was carried out found two variables to be significant at the $\alpha=.05$ level and one variable was found to be significant at $\alpha=.10$. Those who were interested in socializing and discussing productive woodlands (SOCIALIZE) were also more likely to be a participant of the WVWWW $\left(\chi^{2}=15.8332, \mathrm{p}=<0.0001\right)$ (Table 6). Total acreage was also found to be an indicator of participation, where those with less land (1-50 acres) were more likely to be participants $\left(\chi^{2}=5.0780, p=0.0242\right)$. Residency was found to be significant at the $\alpha=.10$ level, as those who were absentee landowners were more likely to be participants of the WVWWW $\left(\chi^{2}=3.5190, \mathrm{p}=0.0607\right)$. 
Table 6. Significant variables associated with West Virginia Woodland Welcome Wagon Participation.

\begin{tabular}{lccc}
\hline Independent variable $^{\mathrm{a}}$ & $\mathrm{OR}^{\mathrm{b}}$ & $95 \% \mathrm{CI}^{\mathrm{c}}$ & $\mathrm{P}>\chi^{2_{\mathrm{d}}}$ \\
\hline Residency & 2.09 & $0.96-4.49$ & $0.061^{*}$ \\
Socialize/discuss & 4.93 & $2.25-10.80$ & $<0.001$ \\
Total Acreage & 0.45 & $0.22-0.90$ & 0.024
\end{tabular}

'Logistic regression using binary dependent variable ‘associated with WVWWW participation', b Odds ratio (OR), ${ }^{\mathrm{c}} 95 \%$ confidence interval of the odds ratio point estimate, ${ }^{\mathrm{d}}$ Probability values for Wald $\chi^{2}$ test for respective independent variables.

$*=$ significant at the .10 level

Recognition of WV woodland related programs

Woodland owners responding to the inquiry (Q 36) of whether they knew certain natural resources management programs, organizations, and agencies showed that several were very well known and others more obscurely known (Figure 5). The West Virginia Forestry Association was the most well-known organization on the list; $68 \%$ of the respondents had recognized this organization. Nearly equal in fame where the WV Forest Stewardship Program and the WV Tree Farm with each having over $40 \%$ of the respondents indicating that they knew of these. WV Christmas Tree Association was another frequently selected organization with $30 \%$ indicating some familiarity with this recognition and certification program. Other less well known were the Managed Timberland Tax Program (20\%; MTTP is a WV tax savings program for managing woodlands), the WV Woodland Owners Association (19\%), the WV Woodland Welcome Wagon project (16\%), Woodland Stewards training and education program (14\%), and the Call Before You Cut Program (11\%). This pattern of program and organization recognition by survey respondents may have to do with the establishment date of these organizations. The 
WV Woodland Stewards program, Call Before You Cut, and the WVWWW are all less than ten years old while the others have all been in existence for at least two decades.

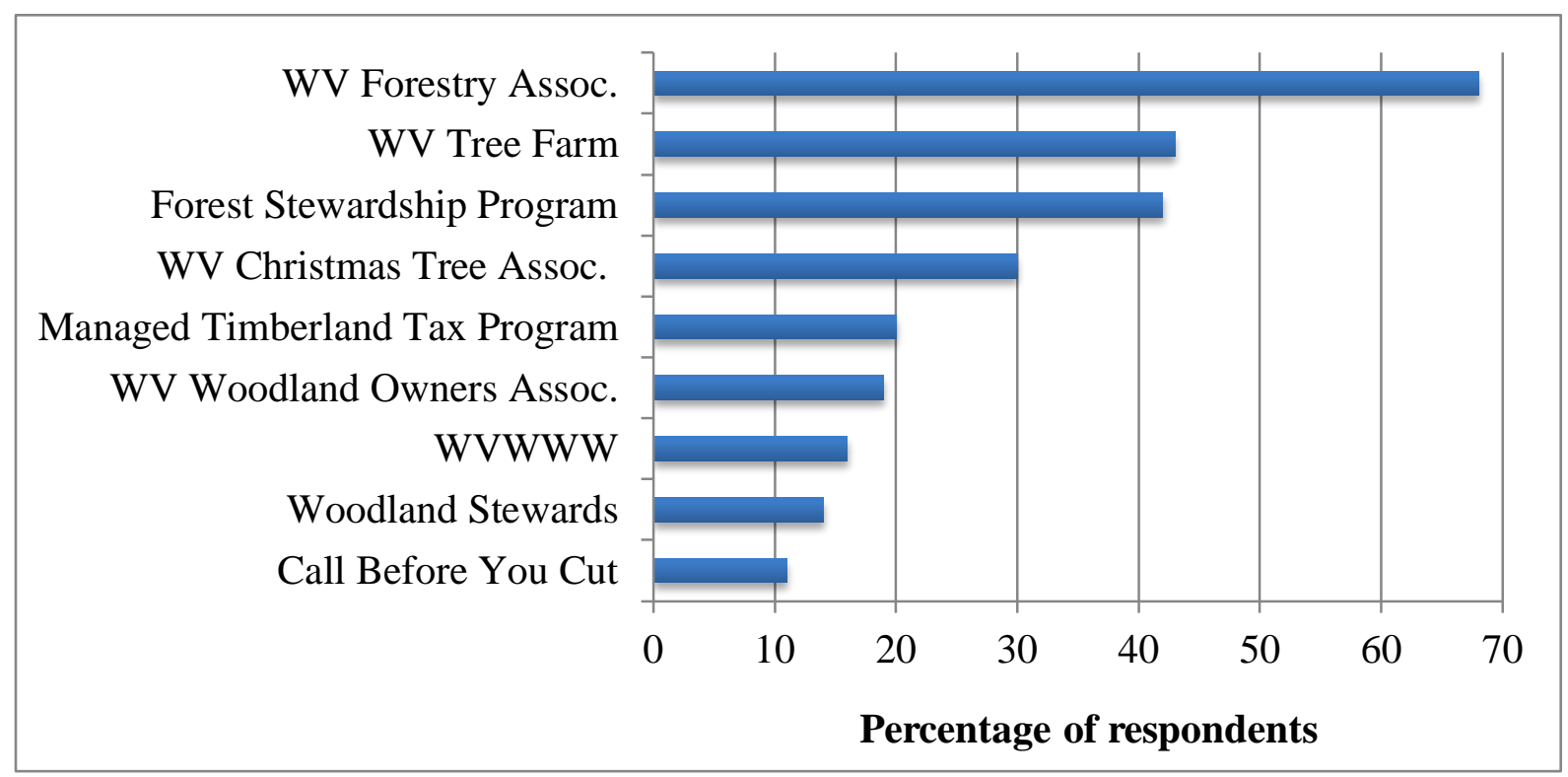

Figure 5. Percentage of respondents reporting that they are familiar with various West Virginia natural resource management organizations, agencies, and programs.

While the WVWWW project was one of the lesser known organizations recognized in the survey, those that had signed up to participate fully in the project were familiar with a statistically greater number of organizations than those not participating fully (Table 7). Respondents who had requested both the informational packet and the invitations to woodland workshops and seminars (HIGH) were familiar with an average of 3.2 natural resources education entities, while those who only received the informational packet and non-participants reported familiarity with only 1.9 and 2.2 , respectively. 
Table 7. Relationship of contact level and the mean number of woodland related organizations with which respondents indicated familiarity.

\begin{tabular}{cccc}
\hline Contact level & & Respondents (n) & $\begin{array}{c}\text { \# of woodland } \\
\text { education } \\
\text { organizations }\end{array}$ \\
\hline & No participation & 104 & $2.2 \mathrm{a}^{1}$ \\
& Send packet & 38 & $1.9 \mathrm{a}$
\end{tabular}

Send packet and workshop

invitations $\quad 53 \quad 3.2 \mathrm{~b}$

${ }^{1}$ Average number of educational organizations that are followed by similar letters are not statistically different at the alpha $=0.05$ level based on Tukey's HSD mean separation procedure.

Two of the programs, the WV Woodland Owners Association and the WV Woodland Stewards project, were recognized by a proportionally greater number of WVWWW HIGH contact participants than the two lower contact classes. Thirty-seven percent of the WVWWW participants who received both packet and invites (HIGH) knew of the WV Woodland Owners Association while in the other two contact levels only $13 \%$ were familiar with the organization (Fisher's Exact Test; $\mathrm{n}=173$; $\mathrm{p}=0.003$ ). The WV Woodland Stewards program, a lesser known education program sponsored by a collaborative effort of natural resource agencies and organizations in the state, also had a similar result with $30 \%$ of the HIGH contact WVWWW respondents familiar with the program, $17 \%$ of the MED contact respondents familiar, and $5 \%$ of the LOW contact respondents familiar with the program (Fisher's Exact Test; $n=168 ; \mathrm{p}<0.001$ ). 


\section{CHAPTER 5}

\section{Discussion}

The West Virginia Woodland Welcome Wagon Project was designed and guided by the findings of Apsley et al. (2005) and their experience with the Ohio Welcome Wagon project. A major modification of the WVWWW project was to allow landowners to request a woodland related resource packet via US Postal Service mail; the request for a resource packet was sent by the respondent via postage paid postcard to the WVWWW project coordinators and the resource packet was sent to back to the requester directly through the mail. This is in contrast to the case in Ohio where woodland owners were required to pick up informational packets at a local extension office (Apsley et al., 2005). We found that this method of distributing information proved more successful and generated nearly a 25\% response rate. Responses from the WVWWW's initial invitation postcards suggest a significant landowner interest in woodland related information. Postcard mailings resulted in $24 \%$ expressing interest in being contacted by the WVWWW project at MED and HIGH levels of participation.

From the recommendation of Ohio Welcome Wagon, we developed a follow up survey to evaluate the program. From our assessment of the program we conclude that their suggestion of sending at least three mailings in the first two years of ownership may be beneficial. As shown with LOW, MED, HIGH contact levels, increasing communication with landowners may elicit more participation. The higher levels of contact (HIGH, MED) also point to higher percentages of recollection and familiarity with certain West Virginia woodland related programs. Thirty percent of the survey respondents indicated that they remembered receiving an invitational postcard from the WVWWW project when, in fact, all 900 were sent a postcard. It was not an 
objective of the WVWWW project to generate brand recognition (Keller, 1993), so it is a bit misleading to look at this statistic as a measure of impact. However, the finding that the level of contact was positively related to the respondents' recall of the project invitation, serves to at least partially substantiate the importance of the recommendation given by Apsley et al. (2005) to carry out at least three mailings to new landowners within the first two years of ownership.

New landowners were the intended target of the WVWWW project. Given the complex organizational structure and differing tax database resources, the strategy chosen to filter out new from old landowners was not perfect. Despite imperfections with the West Virginia tax database, the process allowed us to identify three classes of landowners based on tenure time: 1) recent or "new” landowners, 2) long-term landowners who recently acquired more property, and 3) long-term landowners. Among WVWWW questionnaire respondents, 42\% were new woodland owners. Research on family forests in other areas of the eastern US have seemingly more efficient access to their tax records (Apsley et al., 2005; Kendra and Hull, 2005), yet these other studies made no mention of this additional category; long-term landowners with recent acquisitions. While we did not find any significant statistical difference of this variable indicting participation, this may be a factor to explore. Tenured landowners who are once again purchasing woodland property may be a receptive audience to information about certain management and land use possibilities since it is likely they have a specific intention for acquiring another property. Future research might consider the differential behavior of these general classes of woodland owners and whether they influence the attitudes, preferences, and behavior related to conservation practices.

Some evidence points to an interest in the social benefits as a reason for participating in the WVWWW. This finding is compatible with Allred (2011) who found that over 35\% of 
volunteers in a Master Forest Owner Program listed social connectivity as the "favorite aspect" of being an outreach volunteer. Social appeal may be the primary reason for someone to initially join an outreach education program, as well as being a reason for continuing involvement in the program. Therefore, marketing outreach education programs and woodland owner networks might be made more efficient by promoting the aspects of peer-to-peer interactions and the opportunity to share information with other like-minded landowners. Though it may be hard to target a particular group interested in networking, using the "peer-to-peer" aspect in itself as advertising might produce optimal participation. This study shows there is a definite group of individuals interested in socializing and discussing woodlands. Contrary to expectations, this study also found that total acreage and residence was negatively related to landowner behavior.

The six month time period between the initial WVWWW postcard invitation and the evaluation questionnaire, may not have been enough time to measure impacts, hence is a limitation of this study. Though there is no minimum or maximum time period for assessing results, for this study specifically, it may have been beneficial to wait at least a one year before evaluating this program.

Recommendations for the future this study or for similar studies propose a supplemental followup one year after initial contact to monitor whether actions have been taken during the additional six month time period. We want to reserve the right to maintain these records as confidential for 10 years so that we may inquire about actions taken by respondents in a one year follow-up evaluation. Again, as brand recognition was not a goal of this project, it was not a priority or a measure of impact. However, because of the high percentage of respondents that did not recall contact from the WVWWW, this project in the future will better publicize the program name and goals. It is also recommended that included in the initial invitation cover letter will be a list of 
the resources contained within the woodland information packet. The plans to expand this project to the 45 counties in West Virginia will consider these recommendations as we adapt and modify this project to more successfully reach West Virginia woodland owners. 


\section{LITERATURE CITED}

The American Association for Public Opinion Research. (2011). Standard Definitions: Final Dispositions of Case Codes and Outcome Rates for Surveys. 7th edition. AAPOR

Allred, S. B., Goff, G.R., Wetzel, L.P., Luo, M.K. (2011). Evaluating peer impacts of a master forest owner volunteer program. Journal of Extension [On-line], 49(5) Article 5RIB3. Available at http://www.joe.org/joe/2011october/pdf/JOE_v49_5rb3.pdf

Apsley, D., Bagley, S., Samples, D. (2005) Using a welcome wagon approach to reach out to woodland owners in Appalachian Ohio. Journal of Extension [On-line], 43(1) Article 1IAW4. Available at http://www.joe.org/joe/2005february/iw4.php

Best, C.; Wayburn, L. (2001). America’s Private Forests: Status and Stewardship. Washington, DC: The Pacific Forest Trust, Island Press. 268 p.

Block-Torgerson, K., Kilgore, M.A., Taff, S.J., Snyder, S.A. (2010). Forest land parcelization in northern Minnesota: a multi county assessment. Staff Paper Series No. 212. University of Minnesota, Department of Forest Resources, St. Paul, Minnesota.

Butler, Brett J. (2008). Family Forest Owners of the United States, 2006. Gen. Tech. Rep. NRS-27. Newtown Square, PA: U.S. Department of Agriculture, Forest Service, Northern Research Station. 72 p.

Butler, B.J., Tyrrell, M., Feinberg, G., VanManen, S., Wiseman, L., and Wallinger, S. (2007). Understanding and reaching family forest owners: Lessons from social marketing research. Journal of Forestry, 105(7), 348-357.

Childs, R. A. (2005). West Virginia forests growing West Virginia's future. Bureau of Business and Economic Research, College of Business and Economics, Morgantown, WV; West Virginia University.

Davis, M.L.E.S.; Fly, J.M. (2010). Do you hear what I hear: Better understanding how forest management is conceptualized and practiced by private forest landowners? Journal of Forestry, 108, 321-328.

DeCoster, L.A. (1998). The boom in forest owners - a bust for forestry? Journal of Forestry, 96(5):25-28.

Dillman, D. A. (2000). Mail and Internet surveys--The tailored design method. New York : John Wiley \& Sons, Inc. 
Forthofer MS, Bryant CA. (2000). Using audience-segmentation techniques to tailor health behavior change strategies. American Journal of Health and Behavior, 24:36-43

Gobster, P.H.; Rickenbach, M.G. 2004. Private forestland parcelization and development in Wisconsin's Northwoods: Perceptions of resource-oriented stakeholders. Landscape and Urban Planning, 69(2-3): 165-182.

Gustafson, E.J., Loehle, C. (2006). Effects of parcelization and land divestiture on forest sustainability in industrial forest landscapes. Forest Ecology and Management, 236:305314.

Joshi, S., Arano, K.G. (2006). West Virginia forest landowners: a look at their characteristics and forest management decision. Proceedings of the Southern Forest Economics Workshop, 2006 March 22-24, Emerging Issues in Forest Economics, Knoxville, Tennessee.

Joshi, S., Arano, K.G. (2009). Determinants of private forest management decisions: A study in West Virginia NIPF landowners. Forest Policy and Economics, 11 (2), 132-139.

Keller, K.L. (1993). Conceptualizing, measuring, and managing customer-based brand equity. Journal of Marketing, 57(1):1-22.

Kendra, A., Hull R.B. (2005). Motivations and behaviors of new forest owners in Virginia. Forest Science, 51(2):142-154.

Kittredge, D.B. (2004). Extension/outreach implications for America's family forest owners. Journal of Forestry, 102(7):15-18.

Kotler, P., Zaltman, G. (1971). Social marketing: An approach to planned social change. Journal of Marketing, 35:3-12

Lindner, J. R., Murphy, T. H., \& Briers, G. H. (2001). Handling nonresponse in social science research. Journal of Agricultural Education, 42 (4), 43-53.

Majumdar I, Teeter L, Butler B. (2008). Characterizing family forest owners: A cluster analysis approach. Forest Science, 54(2):176-84.

Mehmood, S., Zhang, D. (2001). Forest parcelization in the United States—A study of contributing factors. Journal of Forestry, 99:30-4

McGill, D.W., D.J. Magill, J. Kochenderfer, W. M. Ford, and T.Schuler. (2004). Information transfer during the timber transaction period inWest Virginia, USA. In Proceedings "Communication Strategies" IUFRO Forestry Extension Conference, Orvieto, Italy September 2004.

Rickenbach, M., and Kittredge, D.B. (2009). Time and distance: Comparing motivations among forest landowners in New England. Small-Scale Forestry 8:95-108. 
Sagor, E. S. (2003). Nonindustrial private forest landowners and sources of assistance. In P. Jakes, Proceedings from "Forestry cooperatives: what today's resource professionals need to know." Nov. 18, 2003. (pp. 3-12). St. Paul, MN.

Salmon, O., Brunson, M., Kuhns, M. (2006). Benefit-based audience segmentation: A tool for identifying nonindustrial private forest (nipf) owner education needs. Journal of Forestry, 104(8), 419-425.

Sampson, R.N., DeCoster, L.A., (2000). Forest fragmentation: implications for sustainable private forests. Journal of Forestry, 98 (3), 4-8.

SAS Institute Inc., SAS 9.1.3 Help and Documentation, Cary, NC: SAS Institute., 2000-2004

Tyson, C.B., S.H. Broderick, Snyder, L.B. (1998). Social marketing approach to landowner education. Journal of Forestry, 96(2):34-40.

US Census Bureau. (2012) U.S. Census Bureau Maps and Cartographic Resources. Available at: <http://www.census.gov/geo/www/maps/>.

Warner, E.L. (2006) Perceptions of land development and conservation in Hampshire County, West Virginia: Implications for the future. (Unpublished master's thesis), Allegheny College, Meadville, Pennsylvania. 


\section{APPENDIX A}

\section{Initial Welcome Letter}

May 6, 2011

Dear Woodland Owner,

We'd like to invite you to be a part of conserving West Virginia’s working landscapes! As a woodland owner, you have lots of opportunities to contribute to the health of the forest, the economic well-being of your family and your community, and to your personal satisfaction as a woodland steward.

The West Virginia Woodland Welcome Wagon is a new project that aims to connect woodland owners with the professional forestry community. In West Virginia there are various programs and agencies that support woodland owners in their continuing education and on-the-ground woodland activities. Our goal is to share with you information about services and organizations that can support you as you establish your ideal woodland.

We'd like to send you an informational packet that describes some of the organizations and programs here in West Virginia that concentrate on woodland stewardship. We can also alert you to upcoming educational workshops that we'll be developing in partnership with the West Virginia Division of Forestry.

To get connected with the West Virginia Woodland Welcome Wagon, please take time to fill out the pre-paid postcard. This postcard will let us know your preference for future contact.

We look forward to hearing from you!

Sincerely,

Dr. Dave McGill

Professor/Extension Specialist

Forest Resources Management
Meg McCuen

WV Welcome Wagon Project Leader

Graduate Research Assistant 


\section{APPENDIX B}

\section{Packet Cover Letter}

May 13, 2011

Dear Woodland Owner,

Enclosed is the packet of information you requested from the initial mailing of the West Virginia Woodland Welcome Wagon. Again, our goal is to share with you information about services and organizations that can support you in your woodland stewardship efforts. We hope you find this information helpful in establishing your ideal woodland.

Most of the enclosed information contains contact phone numbers and email addresses for the individuals and organizations related to the specific topics. Feel free to contact us as well if you need any additional assistance.

Woodland owners who indicated interest in upcoming woodland-related workshops will be receiving notification postcards in the coming weeks. For those who did not indicate interest, you can still see currently available workshops and seminars by visiting the WV Woodland Stewards network at: http://wvstewards.ning.com.

We hope our paths cross soon!

Sincerely,

Dr. Dave McGill

Professor/Extension Specialist Forest Resources Management 304-293-5930

dmcgill@wvu.edu
Meg McCuen

WV Welcome Wagon Project Leader

Graduate Research Assistant

304-293-5741

megmccuen@gmail.com 


\section{APPENDIX C}

\section{Reminder Welcome Letter}

June 20, 2011

\section{Dear Woodland Owner,}

Last month we sent you an invitation to be a part of conserving West Virginia's working woodland landscapes. We'd like to let you know that it is not too late to request the free informational packet that describes some of the organizations and programs here in West Virginia that concentrate on woodland stewardship.

To get connected with the West Virginia Woodland Welcome Wagon, please take time to fill out the pre-paid postcard. This postcard will let us know your preference for future contact and if you wish to be invited to upcoming woodland workshops. If you prefer not to receive the free packet of information, simply check the "no thanks" box on the return postcard.

Our goal is to share with you information about services and organizations that can support you as you establish your ideal woodland. As a woodland owner, you have lots of opportunities to contribute to the health of the forest, the economic well-being of your family and your community, and to your personal satisfaction as a woodland steward.

We look forward to hearing from you!

Sincerely,

Dr. Dave McGill

Professor/Extension Specialist

Forest Resources Management
Meg McCuen

WV Welcome Wagon Project Leader

Graduate Research Assistant 


\section{West Virginia Woodland Owners Survey: Education and Cross-boundary Cooperation}

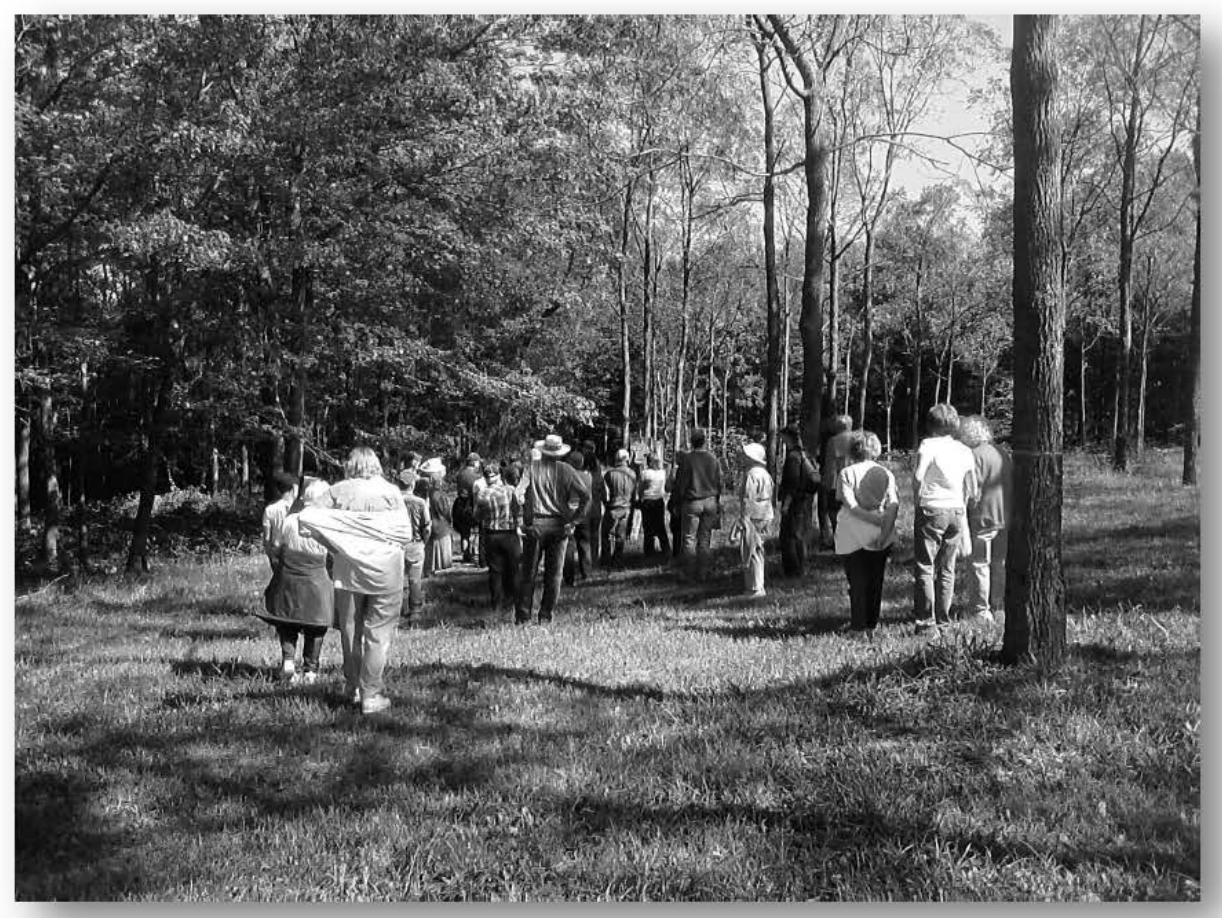

January 2012

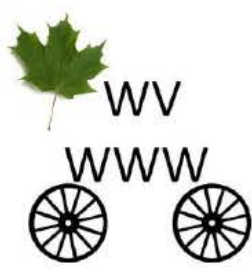

Extension Service

WestVirginiaUniversity.

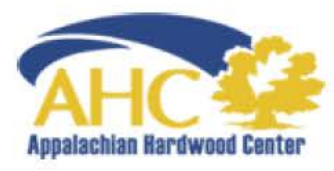


Please return the completed questionnaire in the postage-paid envelope provided to:

Megan McCuen

Appalachian Hardwood Center

West Virginia University Division of Forestry \& Natural Resources

P.O. Box 6125

Morgantown, WV 26506-6125

Please contact Meg McCuen at megmccuen@gmail.com or (304) 293-5741 if you have any questions.

\section{About this Survey}

The purpose of this survey is to gain knowledge about West Virginia woodland owners, what they do in their woodlands, and their experiences working with their neighbors. Healthy forests and woodlands produce benefits not just for individual landowners, but for all society. The majority of West Virginia's forested land is owned by private landowners; when combined, individually owned woodlands significantly impact the whole landscape. Working across property boundaries is one way to promote enhanced environmental quality and to make woodland activities more financially rewarding. Your insights will provide helpful information to guide state and local agencies, and private landowners in important landscape level conservation efforts.

Your participation is voluntary and you have the right to refrain from answering any questions. Please feel free to answer only those questions that you are comfortable answering. If you choose to participate, your answers will be kept confidential.

Thank you for your assistance with this important project!

\section{Instructions:}

- Either a pen or pencil can be used.

- When answering questions that require marking a box, please use an " $\mathrm{X}$ ".

- If you need to change an answer, please make sure that your old answer is either completely erased or clearly crossed out.

\section{START HERE:}

We have acquired your address from a list of landowners. If you do own woodland property, please continue with the survey. If you do not own woodland property, please check the appropriate box and send back the questionnaire in the prepaid envelope. (Check all that apply)

Please send me a summary of the results of this survey.

I do not own woodland property (please return blank questionnaire).

I do own woodland property (please continue with the questionnaire).

I prefer not to participate in this survey (please return blank questionnaire). 


\section{WV Woodland Owners Survey: Education \& Cross-boundary Cooperation}

\section{Property ownership}

1. In what year was your most recent woodland property acquisition in W. Va.?

a. How many acres is this property?

b. Approximately what proportion of this property is woodland? $\%$

c. In what county is this property?

d. Do you still own this property?

2. In total, how many woodland and/or farmland properties do you own?

a. How many total acres does this represent?

b. Approximately what proportion of the total acreage is in woodland? $\%$

3. When did you acquire your first woodland and/or farmland property? (year)

\section{Your most recently acquired property}

Please answer the following questions with regard to your most recently acquired woodlands:

4. How many people are part of the newest woodland ownership?

5. Who makes the management decisions for this woodland?
$\square$ I d
$\square$ Joint decisions by owners
Other:

6. Are you planning to sell or transfer this property within the next ten years?

$\square$ Yes No

7. Do you live on this property?

$\square$ Yes

$$
\text { No }
$$

8. If no, do you have future plans to move to this property?

$\square$ Yes No

9. How long have you been the designated owner or one of the designated owners of the property? years

10. Which category below best describes your ownership? (Check only one)

Individual

Family partnership

Trust or estate

Joint, such as a husband and wife

Corporation or business partnership

Other (please specify)

11. How did you acquire this wooded land in West Virginia? (Check all that apply)

Purchased

Inherited

Received as gift

Other (please specify) 


\section{Woodland activities}

Please answer the following questions with regard to your most recently acquired woodlands:

12. What priorities do you have for your woodland?

(Please rank 1 through 7, 1 being the highest priority, 7 being the lowest priority)

Wildlife

Timber

Residence

Aesthetics

Privacy

Gas/Minerals

Recreation

13. Do you currently have a written Forest Stewardship Plan for your woodland?

$\square$ Yes $\quad \square$ No $\quad \square$ I don't know

$\square$ I have contacted a forester to do this, but do not have the plan yet.

14. Have you ever contacted a professional forester about your woodland property?
$\square$ Yes
No

15. What types of activities, if any, do you perform on your property?(Check all that apply)
$\square$ Tree planting
Wildlife management
Invasive species removal
$\square$ Timber stand improvement
Property boundary maintenance/posting
Herbicide application
$\square$ Road clearing/maintenance
Other:

16. Have you personally ever sold timber from this property?

$\square$ Yes $\square$ No

a. If yes, who was involved in the timber sale and operation? (Check all that apply)

$\square$ Me, the landowner
$\square$ WV Division of Forestry (public forester)
$\square$ Private consulting forester
$\square$ A forester from a wood-using factory
$\square$ A logger who cut the trees
$\square$ A lawyer
$\square$ Other:

17. Have you ever been contacted about selling the timber on this property?
$\square$ Yes
No

18. In the next ten years, how likely is it that you will sell some timber?

$\square$ Very likely $\square$ Somewhat likely $\square$ Not likely $\square$ Don't know

19. How much timber value do you think you have on your property? (Check one)
$\square$ A lot
Some
Not much
None 


\section{Cross-boundary management}

We are interested in finding out how neighboring woodland owners work with one another. If you own more than one property, please answer regarding the property with which you are most familiar.

With respect to your neighbors that share a boundary with you:

20. How many neighboring properties do you have?

a. Of these, I have met neighboring owners of properties. (enter number)

21. On average, how often do you communicate with at least one of your neighbors?

$\begin{array}{ll}\square \text { Daily } & \square \text { Weekly } \quad \square \text { Never } \\ \square \text { Monthly } & \square \text { Other: }\end{array}$

22. How do you communicate with your neighbors? (Check all that apply)

$\begin{array}{ll}\square \text { Telephone } & \square \text { In person } \quad \square \text { I don't communicate with them } \\ \text { Email } & \square \text { other: }\end{array}$

23. Of the neighbors you have met, how many do you know well?

(Check one) $\square$ All $\square$ Most $\square$ Some $\square$ None $\square$ I haven't met any

24. In general, rate the quality of your relationships with your neighboring land owners?

(Check one) $\square$ Excellent $\square$ Good $\square$ Fair $\quad \square$ Poor $\square$ N/A

25. Would one of your neighbors be your first emergency contact for an unexpected event that happens on your woodlands?

$\square$ Yes $\quad \square$ No

26. Are you or do you think you would be an emergency contact for one of your neighbors?
$\square$ Yes
No
I don't know

27. Do your neighbors ever help with work in your woodlands?

$\square$ Yes $\quad \square$ No

a. If yes, please briefly describe:

28. How often do neighbors call upon you to help with their woodland activities?
Frequently
Often
$\square$ Sometimes
Never

29. What are the most common reasons for communicating with your neighbors? 
30. Do you share property boundaries with any relatives? $\square$ Yes $\square$ No

31. Do you share property boundaries with any public lands (e.g., parks, National Forest, State Forests, wildlife management areas, etc.)?

$\square$ Yes $\quad \square$ No

32. Do you share any of the following with the owners of neighboring properties?

(Check all that apply)

$\square$ Tools $\square$ Equipment $\square$ Road access $\square$ Information

$\square$ Costs for road repairs $\quad \square$ Work on fencing $\quad \square$ Other:

$\square$ I don't share any of these

33. How interested would you be in getting together with a group of local woodland owners to:

Socialize/discuss productive woodlands

Learn about wildlife habitat

Build a woodland owner network

Learn and implement road maintenance tips

Learn about property security and safety

Learn about native herbs, trees, and shrubs

Learn how to control weeds

Tour one another's woodlands

34. How willing:

...are you to work with your neighbors?

...are your neighbors in working with you?
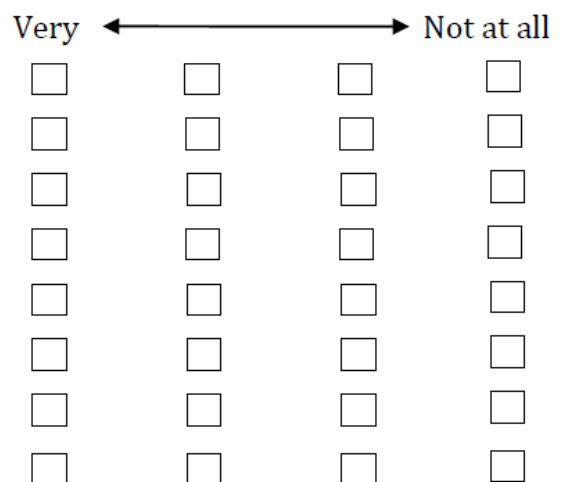

35. Please express how you relate to the following statements. Use a 1 to 10 point scale, with $\mathbf{1 0}$ meaning it describes you completely and $\mathbf{1}$ meaning it doesn't describe you at all.

I generate income from my land or own it for financial investment purposes

I own my land for the enjoyment of the scenery

I own my land for the privacy it affords

I use my land for recreation purposes

I'm not particularly involved with my land 


\section{Woodland Stewardship Education}

36. Have you ever heard of any of the following West Virginia woodland related programs? (Check all that apply)

\begin{tabular}{|c|c|c|c|c|c|}
\hline Yes & No & WV Forestry Association & $\square$ Yes & $\square \mathrm{N}$ & Tree Farm \\
\hline Yes & No & Forest Stewardship & Yes & & Call Before You Cut \\
\hline Yes & No & Woodland Welcome Wagon & Yes & & Woodland Stewards \\
\hline Yes & No & Managed Timberland Tax Program & & & \\
\hline Yes & No & Christmas Tree Growers Association & & & \\
\hline Yes & No & Woodland Owner Association of WV & & & \\
\hline
\end{tabular}

37. What information would be most helpful to you as you manage your woodland?

38. Have you attended a woodland-related workshop since May 2011 (in past 9 months)?

$\square$ Yes $\square$ No

39. Would you attend a local woodland workshop covering a topic that interests you?

$\square$ Absolutely $\square$ Probably $\square$ Possibly $\square$ No

40. Within the past year, have you received a postcard from the WV Woodland Welcome Wagon Project?

$\square \quad$ No (go to Question 41 on next page)

Yes

If yes then: $^{2}$

a. What was your response to the WV Woodland Welcome Wagon postcard?

(Check all that apply)

I did not respond

$\square$ I chose not to participate

$\square$ I asked for the packet

$\square$ I asked to be invited to woodland education workshops.

b. Did you take any new action as a result of contact with the WV Woodland Welcome Wagon Project? If so, please describe.

c. If you received the informational packet, what did you find to be most helpful? 
Demographics - Remember your answers are strictly confidential

Please answer the following questions about yourself:

41. What is your gender? $\square$ Female $\square$ Male

42. What is your age? $\square 18$ - 30 yrs $\square$ 40 - $50 \quad \square 60$ - 70

$30-40 \square 50-60 \quad 70+$

43. What is your current occupation?

44. I reside in:

County

State

45. What is the highest level of education you have completed? (Check only one)

$\square$ Some High School
$\square$ High School Graduate
$\square$ GED
$\square$ Trade or Technical School
$\square$ Some college

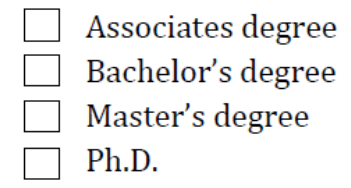

46. What is your average yearly income? (Check only one)

$\square \quad$ Less than 15,000
$\square \quad \$ 15,001-\$ 30,000$
$\square \quad \$ 30,001-\$ 45,000$
$\square \quad \$ 45,001-\$ 60,000$

Any other comments?

Thank you for your help with this survey! 


\section{APPENDIX E}

\section{Pre-Questionnaire Postcard}

\section{Notice of Upcoming Survey}

\section{West Virginia Woodland Owners}

\section{Dear WV Woodland Owner:}

A few days from now you will receive a survey designed to collect information about West Virginia woodland owners. This is part of a research project that is being conducted by West Virginia University. WVU's Institutional Review Board acknowledgement of this study is on file.

We are asking for y our participation. Your insight can provide valuable information about woodland owners and help to guide state and local agencies in important landscape level conservation efforts.

Please look for this questionnaire in your mailbox. It is with your generous help that this research can be successful. Thank you in advance for your participation.

Dave McGill

Professor/Extension Specialist (304) 293-5930; dmcgill@wvu.edu

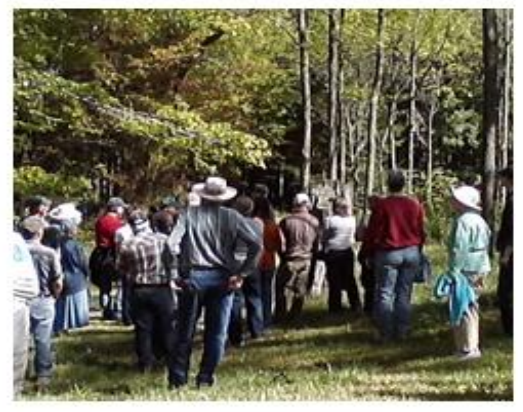




\section{APPENDIX F}

\section{Questionnaire Reminder Letter}

February 7, 2012

Dear West Virginia Woodland Owner:

A month ago we mailed you a questionnaire that is part of a West Virginia University research project seeking information about your knowledge and experience as a West Virginia woodland owner. According to our records, you have not yet returned the survey.

We are writing again because your participation in this survey is important to get accurate results. It is by hearing from a majority that we get a representative view of the actions and attitudes of West Virginia woodland owners. Please consider contributing your experience and knowledge to this research effort.

Again, your participation in this survey is voluntary and you can quit any time without any penalty. You do not have to answer all of the questions, but any information you provide will contribute to the project's success. You must be over 18 years of age to participate. If you do not wish to participate, please let us know by returning the enclosed questionnaire, blank or with a note, in the prepaid envelope provided.

Information you provide is confidential; only summaries will be reported in which no individual's answers can be identified. When you return your completed questionnaire, your name will be deleted from the mailing list and will never be connected to your answers in any way. West Virginia University's Institutional Review Board acknowledgment of this study is on file.

If you have any further questions, please feel free to contact us at the phone numbers below. It is with your generous help that our research can be successful.

Sincerely,

Dr. Dave McGill, Principal Investigator

Professor/Extension Specialist

Forest Resources Management

(304) 293-5930
Megan McCuen

Graduate Research Assistant

WV Woodland Welcome Wagon

(304) 293-5741 


\title{
APPENDIX G
}

\author{
Reminder Postcard
}

Reminder About Important Survey

\section{West Virginia Woodland Owners}

Dear WV Woodland Owner:

A few weeks ago we mailed a survey designed to collect information about West Virginia woodland owners. This is part of a research project that is being conducted by West Virginia University. WVU's Institutional Review Board acknowledgement of this study is on file.

If you have already completed and returned the survey, please accept our sincere thanks. If not, please take a few minutes to do so today. Your insight can provide valuable information about woodland owners and help to guide state and local agencies in important landscape level conservation efforts.

If y ou did not receive a survey or have misplaced it, please call me and I will mail another one immediately. Thank y ou in advance for y our participation.

Dave McGill

Professor/Extension Specialist (304) 293-5930; dmcgill@wvu.edu

\section{WestVirginiaUniversity}

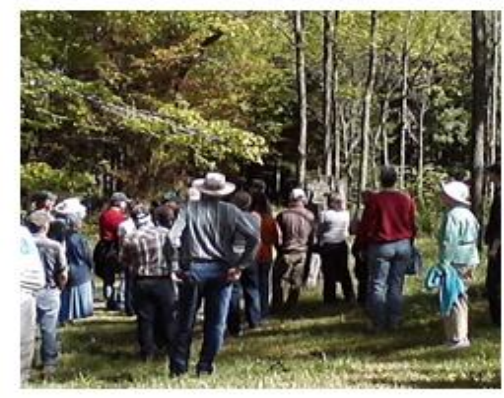

